\title{
SELECTIVE LABELING OF SPIRAL GANGLION AND GRANULE CELLS WITH D-ASPARTATE IN THE AUDITORY SYSTEM OF CAT AND GUINEA PIG ${ }^{1}$
}

\author{
DOUGLAS L. OLIVER, STEVEN J. POTASHNER, DOYLE R. JONES, AND D. KENT MOREST \\ Department of Anatomy, University of Connecticut Health Center, Farmington, Connecticut 06032
}

Received June 28, 1982; reviscd September 16, 1982; accepted September 17, 1982.

\begin{abstract}
The present study sought to locate putative glutamatergic or aspartatergic pathways in the auditory system of cats and guinea pigs. We injected 0.06 to $3 \mathrm{mM} \mathrm{D}-\left[{ }^{3} \mathrm{H}\right]$ aspartate (D-Asp) in the cochlear nucleus before preparation for light microscopic autoradiography. At short survival times (15 and $40 \mathrm{~min}$ ) there was heavy labeling of astrocytic somata. Labeling patterns typical of cochlear nerve endings decorated neurons in the cochlear nucleus, e.g., cell bodies and dendritic trunks of octopus cells. Labeling patterns consistent with retrograde axonal transport by the parallel fibers of granule cells appeared in the molecular layer of the dorsal cochlear nucleus and in the external granular layer. Retrograde labeling of the cochlear nerve root fibers also occurred. Consistent with these results are companion biochemical findings on the rapidly dissected cochlear nuclei of guinea pigs. The dorsal, anteroventral, and posteroventral cochlear nuclei, each, evinced uptake of D-Asp. Subsequently, electrical stimulation of each nucleus released a portion of the accumulated amino acid. Most of this release probably came from synaptic endings.

Another group of experiments compared autoradiographic localization of 0.06 to $3 \mathrm{~mm} \mathrm{D}$-Asp to that of horseradish peroxidase (HRP) $6 \mathrm{hr}$ to $2 \mathrm{~d}$ after injections in the cochlear nucleus. Astroglial cell bodies were no longer labeled by $\mathrm{D}$-Asp, but spiral ganglion cell bodies in the cochlea and granule cell bodies in the cochlear nucleus were. Perikarya of the periolivary and ventral cochlear nuclei projecting to the dorsal cochlear nucleus were labeled by HRP and not by D-Asp. Thus, comparisons with the HRP findings indicate that D-Asp labeling resulted from a selective retrograde transport. There was no evidence for a selective anterograde axonal transport.

The present observations support the hypothesis that cochlear nerve fibers and granule cells may use L-glutamate and/or L-aspartate as a transmitter in the cochlear nucleus.
\end{abstract}

The synaptic organization of the cochlear nucleus plays a key role in the interpretation of acoustic information by the brain. The cochlear nucleus is a complex structure of discrete, well defined subdivisions (Brawer et al., 1974) distinguished by different kinds of synaptic organization, i.e., the types of neurons and their synaptic junctions, local circuits, and connections with cochlear nerve fibers and with other auditory nuclei in the superior olive, lateral lemniscus, and inferior colliculus. Specific kinds of synaptic organization in the subdivisions of the cochlear nucleus have been correlated with characteristic unit firing patterns in response to acoustic stimuli (Morest et al., 1973; Cant and Morest, 1979a,b; Tolbert et al., 1982). For example, bushy cells in the anteroventral cochlear

1 This work was supported by United States Public Health Service Grants 5 RO1 NS14347, 5 F32 NS00068, and grants from the Deafness Research Foundation. We wish to thank L. T. Andrus, S. Kwok, and C. Sowers-Clift for technical assistance. nucleus (AVCN) receive a preponderance of their excitatory input from a few, large cochlear nerve endings, which maintain a high degree of synaptic security. This synaptic organization preserves the signal transmitted by the cochlear nerve fibers. By contrast, fusiform cells in the dorsal cochlear nucleus receive only a fraction of their input from the cochlear nerve and a large input from interneurons, such as granule cells. This kind of synaptic organization can produce significant transformations in the sensory signal. Where correlations can be established between specific kinds of synaptic organization and morphologic types of neurons, on the one hand, and physiological response patterns, on the other, there may be an opportunity to explain the mechanisms that generate the response patterns of these neurons to acoustic stimuli (Morest, 1975). Such explanations would depend in part on information about the transmitters used at particular synapses.

The transmitters in the cochlear nucleus are likely to 
include acetylcholine (Comis and Guth, 1974; Godfrey et al., 1977a; Godfrey et al., 1981; Kimura et al., 1981), norepinephrine (Fuxe, 1965; Anden et al., 1966; Kromer and Moore, 1976), and several amino acids. L-Glutamate and/or L-aspartate (L-Glu/L-Asp) have been proposed as cochlear nerve transmitters. Destruction of the nerve produces decrements in the nucleus in the concentration of these compounds (Godfrey et al., 1977b; Wenthold and Gulley, 1977; Godfrey et al., 1978; Wenthold, 1978; Wenthold and Gulley, 1978; Canzek and Reubi, 1980), in the amounts synthesized (Canzek and Reubi, 1980), in the activities of transmitter-related enzymes (Wenthold, 1980), and in the amounts of L-Glu/L-Asp released from the nucleus (Wenthold, 1979; Canzek and Reubi, 1980). Moreover, neurons in the AVCN rcceiving cochlear afferents apparently have synaptic receptors for acidic amino acids (Martin and Adams, 1979; Martin, 1980; Caspary et al., 1981). Transmitter roles for GABA and glycine are also likely (Wenthold and Morest, 1976; Godfrey et al., 1977a, b; Canzek and Reubi, 1980; Wenthold, 1979; Davies, 1975, 1977; Fisher and Davies, 1976).

Most of the neurons which might use these compounds as transmitters remain to be identified. This should be possible with autoradiographic localization of transmitter-related markers (Iversen and Schon, 1973; Droz, 1975). For example, D-Asp may be a useful marker for L-Glu/L-Asp-utilizing neurons. L-Glu, L-Asp, and D-Asp are probably taken up by the same high-affinity transporter into glia and axonal endings of glutamatergic or aspartatergic neurons (Davies and Johnston, 1976; Balcar and Johnston, 1972, 1973; Johnson, 1978; Hökfelt and Ljungdahl, 1975; Iversen, 1977). After uptake D-Asp is not significantly metabolized for several hours (Davies and Johnston, 1976; 'Takagaki, 1978). Uptake and retrograde transport of $\mathrm{D}$-Asp have been reported in neurons which are presumed, on the basis of other evidence, to use L-Glu/L-Asp as a transmitter (Streit, 1980; Beaudet et al., 1981). Finally, D-Asp can be released in a $\mathrm{Ca}^{2+}$ dependent manner from pathways using L-Glu/L-Asp as transmitters (Malthe-Sorenssen et al., 1979, 1980; Beaudet et al., 1981).

The primary aim of this study was to identify the types of neurons projecting to the cochlear nucleus and those intrinsic to the cochlear nucleus which could be labeled by D-Asp. We first tested whether $\mathrm{D}$-Asp could gain access to axon terminals by measuring electrically evoked release of D-Asp in vitro. We then injected D-Asp into the cochlear nucleus and followed its distribution autoradiographically in situ over a 48-hr period. Shortly after injection, label was localized in certain axons and glia. Later the label disappeared from glia and was apparently transported retrogradely to the perikarya of spiral ganglion cells in the cochlea and granule cell bodies in the cochlear nucleus. These results are consistent with the proposal that granule cells and cochlear nerve fibers use L-Glu/L-Asp as a transmitter.

\section{Materials and Methods}

Uptake and release of $D$-Asp from the cochlear $n u$ cleus in vitro. Albino guinea pigs (350 to $450 \mathrm{gm}$ ) were stunned and decapitated, and the eighth nerve root was carefully cut, before the medulla was excised, placed in ice-cold Ringer, and bisected in the midline with a scalpel. The anteroventral (AVCN), posteroventral (PVCN), and dorsal cochlear (DCN) nuclei were dissected with scissors from each medulla. Approximately $12 \mathrm{~min}$ elapsed from decapitation until the left and right seg. ments of each subdivision were pooled and placed in 0.5 $\mathrm{ml}$ of fresh Ringer, where they stayed at $37^{\circ} \mathrm{C}$ for $20 \mathrm{~min}$ to recover from the dissection. Segments were then placed in $0.5 \mathrm{ml}$ of fresh Ringer containing $1 \mu \mathrm{Ci}(1.2$ $\mu \mathrm{M})$ of D-Asp $\left(\left[2,3-{ }^{3} \mathrm{H}\right]\right.$ aspartate $)$. After $45 \mathrm{~min}$, tissue segments were either analyzed to determine D-Asp uptake or used to measure D-Asp release.

To measure D-Asp uptake, segments were homogenized in $85 \%$ ethanol or $5 \%$ trichloroacetic acid. The radioactivity in these extracts was measured by liquid scintillation spectrometry. After substracting the radioactivity trapped in the extracellular spaces of the segments at the time of homogenization, uptake was expressed as the ratio of radioactivity in the tissue to that in an equivalent weight of medium. The volume, and thereby the weight, of the extracellular fluid in the tissues was determined in separate experiments with [carboxy. ${ }^{14} \mathrm{C}$ ]inulin.

To measure D-Asp release, segments were placed in a superfusion cell $\left(0.5 \mathrm{ml}, 35^{\circ} \mathrm{C}\right)$ and continually superfused with fresh isotope-free medium at a rate of $0.5 \mathrm{ml} / \mathrm{min}$. Superfusate medium that had passed over the tissues was collected in 2-min fractions. After 22 min of superfusion, $4 \mathrm{~min}$ of electrical field stimulation was used to evoke the release of D-Asp. Details of the apparatus and the electrical circuitry are described elsewhere (Potashner, 1978). The parameters of the electrical stimulation are given in Table I. After a total of $38 \mathrm{~min}$ of superfusion, tissue segments were homogenized in $85 \%$ ethanol. The radioactivity in these extracts and in each collected superfusate fraction was measured by liquid scintillation counting. To represent graphically the amount of D-Asp released as a function of superfusion time, the radioactivity released into the superfusion medium was expressed as "the fraction of the tissue radioactivity lost per min of superfusion" (F). To represent quantitatively only the $D$-Asp released as a result of electrical stimulation, the "Aractional stimulus evoked release" (fSER) was computed using the equation: $f S E R=\left(R_{E V}-R_{S P}\right) / R_{T}$, where $R_{E V}$ is the total amount of D-Asp released during the period of elevated release initiated by electrical stimulation, $R_{S P}$ is the computed amount of D-Asp that would have been spontaneously released during this period (the computed average of the spontaneous release immedi-

\section{TABLE I}

Electrical field stimulation of subdivisions of the cochlear nucleus

Rectangular pulses, generated by a Grass stimulator, were made biphasic and passed through the superfusion cell for $4 \mathrm{~min}$. The parameters below were monitored on an oscilloscope. The electrical circuitry employed and the waveforms monitored in the superfusion cell were described previously (Potashner, 1978).

\begin{tabular}{lccc}
\hline \multirow{2}{*}{ Subdivisions } & \multicolumn{3}{c}{ Parameters } \\
\cline { 2 - 4 } & Frequency $(\mathrm{Hz})$ & Duration $(\mathrm{msec})$ & Current $(\mathrm{mA})$ \\
\hline AVCN & 200 & 2.0 & 40 \\
PVCN & 100 & 2.0 & 60 \\
DCN & 100 & 2.0 & 60 \\
\hline
\end{tabular}


ately before and after the period of elevated release), and $R_{T}$ is the amount of D-Asp in the tissue at the start of the electrical stimulation (the amount of D-Asp in the tissue at the end of the experiment plus the amounts released after the stimulation began).

Ringer at $\mathrm{pH} 7.4$ used in the various stages of this procedure was constantly bubbled with a stream of $95 \%$ oxygen-5\% carbon dioxide and usually contained the following ingredients, in $\mathrm{mM}$ concentrations: $\mathrm{NaCl}, 122$; $\mathrm{KCl}, 3.1 ; \mathrm{MgSO}_{4}, 1.2 ; \mathrm{CaCl}_{2}, 1.3 ; \mathrm{KH}_{2} \mathrm{PO}_{4}, 0.4 ; \mathrm{NaHCO}_{3}$, 25; D-glucose, 3 . However, the medium in which newly dissected segments were allowed to recover contained 10 mM D-glucose. In some experiments, all but $30 \mathrm{~mm} \mathrm{NaCl}$ was replaced by an equiosmolar concentration of sucrose (designated $30 \mathrm{Na}^{+}$-sucruse Ringer).

Anatomical experiments. Six cats and six guinea pigs were used in anatomical experiments to localize D-Asp after in vivo injections. Surgical anesthesia was achieved with pentobarbital ( $35 \mathrm{mg} / \mathrm{kg}$, for cats) or chloral hydrate (350 $\mathrm{mg} / \mathrm{kg}$, for guinea pigs). Injections of D-Asp were made through micropipettes with $15-$ to $100-\mu \mathrm{m}$ tips mounted in a micromanipulator and coupled to a hydraulic injection system driven by a syringe pump. The injected solution was prepared at one of three concentrations, $0.06,0.6$, or $3.0 \mathrm{~mm}$ (specific activity, $16 \mathrm{Ci} / \mathrm{mmol}$ ). After surgical exposure of the cochlear nucleus or inferior colliculus and injection of the isotope, the experimental animals were allowed to survive for either $0.25,0.7,6,18$, or $48 \mathrm{hr}$. For the shorter survival times, the subjects were sacrificed by cardiac perfusion of a fixative containing $2 \%$ paraformaldehyde and $5 \%$ glutaraldehyde in $0.12 \mathrm{~m}$ phosphate buffer. Long term survival experiments utilized fixatives routinely used for electron microscopy (Morest, 1975) that contain 3 to $5 \%$ glutaraldehyde. Cochleas were perfused separately with the same fixatives. The experiments are summarized in Table II.

Cat and guinea pig brainstems were sectioned on a freezing microtome at $30 \mu \mathrm{m}$. In some cases, the guinea

TABLE II

Summary of injections of $D \cdot A s p$ used in anatomical experiments D-Asp Injected

$\begin{array}{cccc}\text { Animal } & \begin{array}{c}\text { Survival } \\ \text { Time }\end{array} & \begin{array}{c}\text { Concentra- } \\ \text { tion }(M)\end{array} & \begin{array}{c}\text { Vol- } \\ \text { ume } \\ (\mu l)\end{array}\end{array}$

\begin{tabular}{lllll}
\hline \multicolumn{2}{l}{ Guinea Pigs } & & & \\
GP2071880 & $15 \mathrm{~min}$ & $6 \times 10^{-4}$ & 0.80 & AVCN, PVCN, DCN \\
GP2072380 & $15 \mathrm{~min}$ & $6 \times 10^{-5}$ & 1.00 & AVCN, PVCN, DCN \\
GP3072380 & $15 \mathrm{~min}$ & $6 \times 10^{-4}$ & 1.00 & AVCN, PVCN, DCN \\
GP4072380 & $40 \mathrm{~min}$ & $6 \times 10^{-5}$ & 1.00 & AVCN, PVCN, DCN \\
GP1042881 & $6 \mathrm{hr}$ & $6 \times 10^{-5}$ & 0.50 & DCN \\
GP2042881 & $18 \mathrm{hr}$ & $6 \times 10^{-5}$ & 0.50 & DCN \\
Cats & & & & \\
C2070180L & $20 \mathrm{~min}$ & $3 \times 10^{-3}$ & 3.00 & AVCN, PVCN, DCN \\
C1060381 & $5 \mathrm{hr}$ & $3 \times 10^{-3}$ & 2.50 & AVCN, PVCN, DCN \\
C1060480 & $2 \mathrm{~d}$ & $3 \times 10^{-3}$ & 1.40 & AVCN, PVCN, DCN \\
C2070180R & $2 \mathrm{~d}$ & $3 \times 10^{-3}$ & 0.05 & DCN \\
C1101480 & $1 \mathrm{~d}$ & $6 \times 10^{-4}$ & 1.50 & Inferior colliculus \\
C1111880 & $2 \mathrm{~d}$ & $3 \times 10^{-3}$ & 0.10 & DCN \\
C1102980 & $2 \mathrm{~d}$ & $3 \times 10^{-3}$ & 2.00 & AVCN, PVCN, DCN
\end{tabular}

${ }^{a}$ Illustrated in Figure 2. pig cochlear nucleus was embedded in JB-4 water-soluble plastic (Polyscience) and sectioned with glass knives at $3 \mu \mathrm{m}$. Cochleas were embedded either in JB-4 plastic and sectioned at $5 \mu \mathrm{m}$ or in Spurr's low viscosity plastic or in Epon and sectioned at 1 to $3 \mu \mathrm{m}$. Sections were prepared for light microscopic autoradiography by defatting frozen sections, dipping in NTB-2 emulsion, exposure over dessicant at $4^{\circ} \mathrm{C}$, and development in D19 (full strength) at $13^{\circ} \mathrm{C}$ (Cowan et al., 1972; Oliver and Hall, 1975). Autoradiograms of two cochleas embedded in plastic were treated in a standard photographic fixer containing potassium iodide $(0.2 \mathrm{gm} / \mathrm{liter})$ in order to counteract the negative effects of peroxides released during photographic fixation (Stevens, 1980). In these experiments several series of sections were processed in every case and developed after different exposure times. A typical exposure series was $3,9,30$, and 60 days. Cochleas were exposed up to 27 weeks. After development and fixation, the autoradiographs were counterstained with cresyl violet or toluidine blue and examined with bright-field, dark-field, and Nomarski optics.

In six additional cats, injections of $20 \%$ HRP, 5 to $10 \%$ $\left[{ }^{3} \mathrm{H}\right] \mathrm{HRP}$, or 5 to $10 \%$ wheat germ agglutinin conjugated with HRP (WGA-HRP) were made in the cochlear nucleus and inferior colliculus with the same surgical exposure and injection apparatus. After a survival time of 1 to 2 days, perfusion with mixed aldehyde fixatives containing $1 \%$ or less paraformaldehyde, dissection, and overnight storage in phosphate buffer containing $30 \%$ sucrose, the brains were sectioned on a freezing microtome at 30 to $50 \mu \mathrm{m}$. To visualize the enzyme, several series of sections were processed with tetramethyl-benzidine (Sigma; Mesulam, 1978), $p$-phenylenediamine and pyrocatechol (Polyscience; Hanker et al., 1977), or acid diaminobenzidine (Sigma; Streit and Reubi, 1977). The material was examined with the same optical systems used for autoradiography.

\section{Results}

Uptake and release of $D$-Asp in vitro. When dissected segments of the cochlear nucleus are incubated with 1.2 $\mu \mathrm{M}$ D-Asp for $45 \mathrm{~min}$, they accumulate the amino acid to a higher concentration than that in the medium (see Table III, "Uptake"). During the subsequent superfusion of the segments with isotope-free solutions for $38 \mathrm{~min}$, there is a spontaneous loss of approximately 0.8 to $1 \%$ per min of the accumulated radioactivity to the medium (Table III, "Spontaneous Release"). Electrical stimulation of the segments during this period of superfusion evokes a transient increase in the amount of radioactivity lost to the medium (Fig. 1, white symbols; Table III, "Electrically Evoked Release"). Chromatographic analysis of several samples of the superfusion medium (see Potashner, 1978) shows that more than 95\% of the released radioactivity co-migrated with aspartate. This, along with the failure of others to detect metabolism of D-Asp by brain tissues (Davies and Johnston, 1976; Takagaki, 1978), suggests that the radioactive material released into the superfusion medium was D-Asp.

Both the spontaneous and the electrically evoked releases of D-Asp become larger when glucose-free incubation and superfusion solutions are used (Table III). 
TABLE III

Action of glucose and $\mathrm{Na}^{+}$deprivation on the uptake and release of D-aspartate by segments of the guinea pig cochlear nucleus Dissected segments of the cochlear nucleus were preincubated, then incubated in fresh medium containing $1.2 \mu \mathrm{M} \mathrm{D}$-Asp. After 45 min, some tissue segments were homogenized to determine D-Asp uptake, while others were superfused with isotope-free medium to measure D-Asp release. The uptake denotes the amount of D-Asp associated with the cellular elements of the segments at the close of the incubation in medium containing D-Asp. The spontaneous release refers to the rate of D-Asp release during the superfusion, but immediately prior to electrical stimulation of the segments. The electrically evoked release denotes the release of D-Asp produced by electrical stimulation of the tissues. The units of these values are described in the "Materials and Methods." Data are means $\pm \mathrm{SE}$.

\begin{tabular}{|c|c|c|c|c|c|c|c|c|c|c|c|c|}
\hline & \multicolumn{4}{|c|}{ Uptake (T/M ratio) $)^{a}$} & \multicolumn{4}{|c|}{ Spontaneous Release $\left(10^{3} \times \mathrm{F}\right)$} & \multicolumn{4}{|c|}{ Electrically Evoked Release $\left(10^{3} \times\right.$ fSER $)$} \\
\hline & $\mathrm{AVCN}$ & PVCN & $\mathrm{DCN}$ & $\mathrm{N}^{3}$ & $\mathrm{AVCN}$ & PVCN & $\mathrm{DCN}$ & N & $\mathrm{AVCN}$ & PVCN & $\mathrm{DCN}$ & $\mathrm{N}$ \\
\hline Ringer & $15.0 \pm 1.4$ & $15.6 \pm 2.2$ & $27.1 \pm 5.0$ & 8 & $7.8 \pm 0.5$ & $6.1 \pm 0.5$ & $4.0 \pm 0.4$ & 8 & $2.7 \pm 1.0$ & $2.7 \pm 0.8$ & $1.9 \pm 0.7$ & 5 \\
\hline $30 \mathrm{Na}^{+}$-Sucrose Ringer & $11.6 \pm 1.1$ & $11.7 \pm 1.4$ & $20.8 \pm 2.7$ & 10 & $10.7 \pm 0.6$ & $11.8 \pm 0.7$ & $10.6 \pm 1.6$ & 8 & $14.1 \pm 1.7$ & $14.3 \pm 1.7$ & $13.6 \pm 0.6$ & 5 \\
\hline
\end{tabular}

"Tissue to medium ratio.

${ }^{b}$ Number of observations.
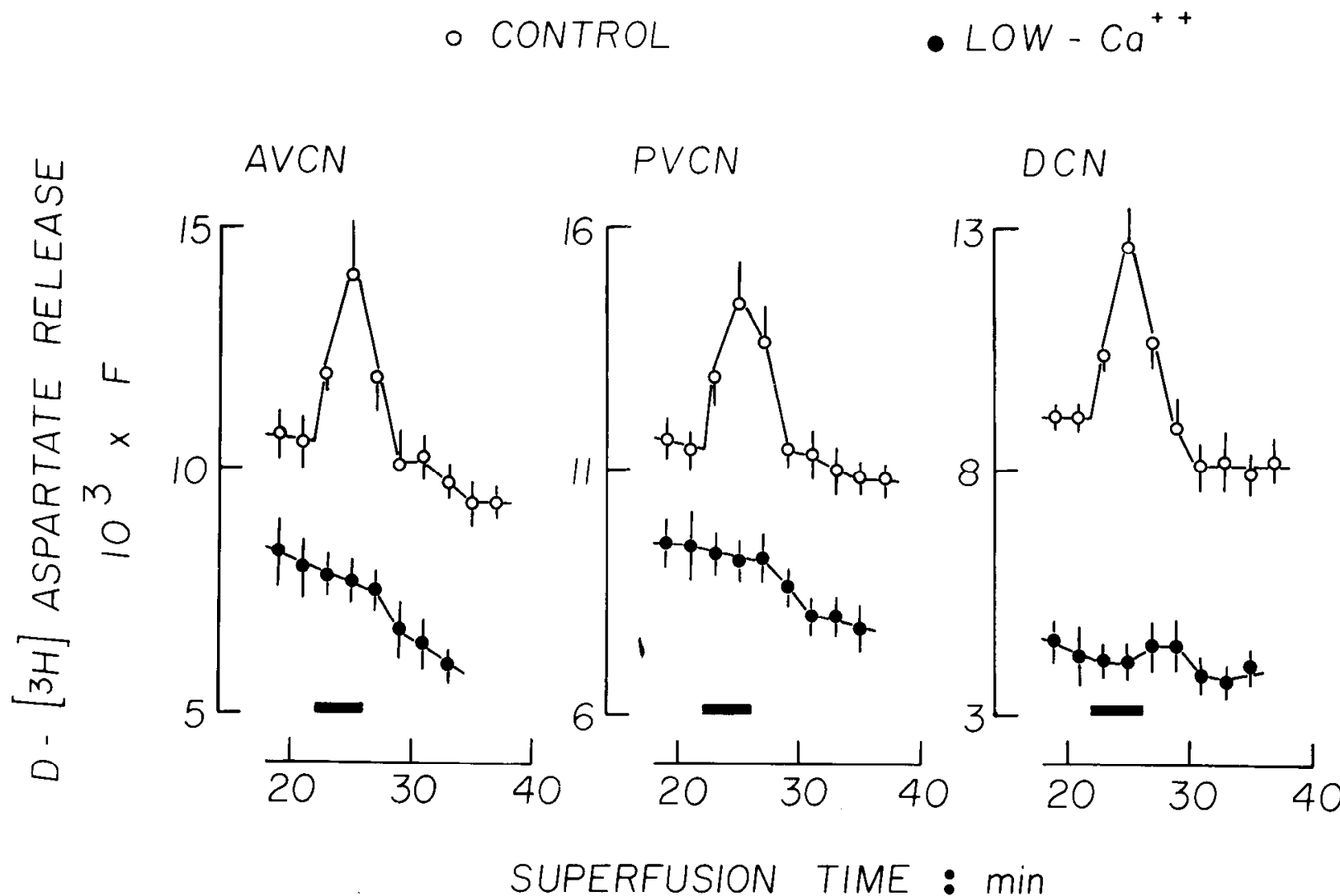

Figure 1.2 Eleclrically evoked, $\mathrm{Ca}^{2+}$-dependent release of D-Asp from the guinea pig cochlear nucleus. Preincubated segments of the guinea pig cochlear nucleus were incubated with $1.2 \mu \mathrm{M} \mathrm{D}$-Asp for $45 \mathrm{~min}$, then superfused with $\mathrm{D}$-Asp-free $30 \mathrm{Na}^{+}$-sucrose Ringer. After $22 \mathrm{~min}$ of superfusion, the tisues were electrically stimulated for 4 min (black horizontal bars). In several experiments (designated as LOW-Ca ${ }^{2+}$ ), the concentration of $\mathrm{CaCl}_{2}$ in the superfusion medium was reduced from $1.3 \times 10^{-3}$ to 1.3 $\times 10^{-5} \mathrm{M}$, with the concomitant addition of $2 \times 10^{-3} \mathrm{M} \mathrm{MgCl}_{2}$ to the medium. This decreased the spontaneous efflux of $\mathrm{D}$-Asp from the tissue and virtually abolished the electrically evoked release. The data above are means \pm SE of three to six experiments. $F$, fraction of tissue D-Asp lost per min.

This suggests that glucose-dependent processes might diminish the amount of D-Asp leaving the tissues and appearing in the superfusion medium. Perhaps a more prominent uptake of $\mathrm{D}$-Asp in the presence of glucose

\footnotetext{
'The abbreviations used in the figures are: Cochlear nucleus: A, AVCN. Anterior division: $\Lambda \Lambda$, anterior part; AP, posterior part; APD, posterodorsal part; posterior division: $\mathrm{PD}$, dorsal part; $\mathrm{PV}$, ventral part, including cochlear nerve root; $\mathrm{P}, \mathrm{PVCN}$ : $\mathrm{AD}$, anterodorsal part; $\mathrm{DO}$, dorsal part; PA, anterior part; OC, octopus cell area; D, Dorsal cochlear nucleus (DCN): ml, molecular layer; fcl, fusiform cell layer; pl, poly-
}

recaptures some of the D-Asp lost spontaneously and during electrical stimulation. Since uptake of D-Asp requires $\mathrm{Na}^{+}$ions (Davies and Johnston, 1976), partial replacement of the $\mathrm{NaCl}$ in the medium with sucrose

morphic layer; g, granule cell region; scc, small cell cap. Other regions: $\mathrm{B}$, bone; $\mathrm{CB}$, cerebellum; $\mathrm{ChPl}$, choroid plexus; $\mathrm{CN}$, cochlear nerve root; E, emulsion; IC, inferior colliculus; LL, lateral lemniscus; NspV, spinal trigeminal nucleus; RB, restiform body; SG, spiral ganglion; SOC, superior olivary complex; TB, trapezoid body; VN, vestibular nerve root; $\mathrm{V}$, trigeminal nerve root. 
should reduce the uptake, making more D-Asp available for collection. Segments incubated and superfused in 30 $\mathrm{Na}^{+}$-sucrose Ringer take up 23 to $25 \%$ less D-Asp (see also Davies and Johnston, 1976) and release more D-Asp spontaneously and during electrical stimulation than do tissues kept in the equivalent full- $\mathrm{Na}^{+}$Ringer (Table III). Since the electrically evoked release is considerably larger in $30 \mathrm{Na}^{+}$-sucrose Ringer, the subscquent experiment was performed using this solution.

Glia and axon endings using L-Glu/L-Asp as transmitters presumably possess the high-affinity transporter mediating the uptake of D-Asp (see Johnson, 1978). If D-Asp accumulated by segments of the cochlear nucleus is located in glia and in axon endings of some neurons, electrical stimulation may evoke release of D-Asp from transmitter pools of L-Glu/L-Asp in axon endings. After excitation of axon endings, entry of extracellular $\mathrm{Ca}^{2+}$ ions probably initiates the release of the transmitter (Rubin, 1974). Thus, $\mathrm{Ca}^{2+}$ deprivation should block the transmitter releasing mechanism and, thus, any synaptic release of D-Asp. When release is measured using incubation and superfusion solutions having only $1 \%$ of the $\mathrm{Ca}^{2+}$ in control media, the electrically evoked release of D-Asp is virtually abolished (Fig.1). This implies that in control media the electrically evoked release of D-Asp probably comes from axon endings and that some axon endings in these tissues contain D-Asp.

Early localization of D-Asp in situ. Electrical stimulation in vitro released only a small fraction (approximately $1.4 \%$ ) of the total amount of D-Asp in the dissected segments of the cochlear nucleus. This suggests that after $40 \mathrm{~min}$, most of the D-Asp initially accumulated by the tissue was not near release sites but may have been in other parts of the neurons and in glia. To determine the cellular localization of D-Asp in the cochlear nucleus, animals were sacrificed for autoradiography 15 and 40 min after injections of various concentrations of D-Asp, including those near the $\mathrm{K}_{\mathrm{m}}$ for its high-affinity uptake (Davies and Johnston, 1976). The observations were similar in the cat and guinea pig; the best localizations were seen in 3- $\mu \mathrm{m}$-thick plastic sections after an injection of the lowest concentration $(0.06 \mathrm{~mm})$. The label visualized by autoradiography was probably in the form of DAsp, as metabolism of D-Asp was not detectable by Davies and Johnston (1976) after exposing brain slices to the amino acid for up to $90 \mathrm{~min}$.

A characteristic labeling pattern appeared within the injection sites. The injection sites were defined by the heavy labeling of the neuropil and of the glial cell bodies. Often the glial cell bodies in the injection site were so heavily labeled in long exposure autoradiographs as to obscure totally the internal cellular structure. In such material a distinct transition from the area of heavy glial labeling to the areas of light or imperceptible glial labeling could be perceived. That transition seemed to occur approximately in the same region, more or less, where there was a decrease in the overall labeling of the neuropil, although this was more difficult to pinpoint. Thus, it was possible to define an injection site by using the labeling over glial cell bodies (Table II). In two of the guinea pigs, the injection sites occupied most of the PVCN and DCN and part of the AVCN (caudal region of the posterodorsal part) but usually not any portion of the primary cochlear nerve root in the entry zone (posteroventral part of AVCN) (Fig. 2).

In the neuropil of the injection site, the features of the labeling pattern suggest the presence of D-Asp in axonal endings (Fig. 3, $A$ and $B$ ). Heavily labeled profiles around the large neuronal perikarya in the ventral cochlear nucleus resemble cochlear nerve endings. Dense, thick clusters of silver grains, resembling typical end bulbs of cochlear nerve fibers, could be localized on the perikaryal perimeter of cell types known to receive these large axosomatic endings (Fig. $3 A$, ). At the same time, there appears to be abundant labeling over smaller, perisomatic structures that could represent the smaller cochlear nerve endings (Fig. 3A). These structures could not be distinguished from small noncochlear endings or glial processes in the light microscope, but this labeling pattern is reminiscent of the cochlear nerve endings which are associated with stellate cells in the ventral cochlear nucleus. Both types of perisomatic profiles have been seen in the cochlear nucleus after cochlear injections of $\left[{ }^{3} \mathrm{H}\right]$ leucine and anterograde transport into the endings of the cochlear nerve (Jones and Casseday, 1979).

The labeling of glial cell bodies and their processes was prominent in the injection sites (Fig. $3, B$ to $D$ ). These small cells were distinguished from neurons by their distribution and morphology. For example, the scattered distribution of the glia does not correspond to the laminar arrangement of the neurons in the DCN (Fig. $4 A$ ). Even the smallest neurons, the granule cells, are distinguished from glia by their slightly bigger size, their clear nucleus, and large prominent nucleolus. The glial cell bodies have the size, shape, and nuclear morphology characteristic of astrocytes (Fig. 3, $C$ and $D$ ).

At longer survival times the appearance of the label in fibers of the cochlear nerve root and the molecular layer of the DCN provides more evidence for early uptake by axonal endings. At $40 \mathrm{~min}$ after injection, the cochlear nerve root contains a labeling pattern consistent with retrograde transport by nerve fibers or fascicles of fibers (Fig. 5, $C$ and $D$ ). Silver grains stream heavily along the nerve root fascicles from the injection site to the cut end of the cochlear nerve stump at the lateral margin of the posteroventral part of AVCN. The primary root and descending branch of the nerve were labeled, but only the dorsocaudal portion of the ascending branch was labeled in the injection site (posterodorsal part of AVCN). Glial cell bodies were labeled proximally but not at the cut end of the nerve root. By contrast, at $15 \mathrm{~min}$ after injection, the nerve root was scarcely labeled at all (Fig. 5, $A$ and $B$ ). Nevertheless, a decrease is visible in the labeling intensity with distance from the injection site. Also, at $15 \mathrm{~min}$, glial cell bodies in the nerve root were seldom, if ever, labeled, while the sparse streams of silver grains seemed to pass over the fibers and to either side of the glial cell bodies. The reverse pattern appeared in the dorsal acoustic stria, which contains the output fibers from the DCN and emerges medially from the injection site (Fig. 6B). Rings of silver grains girdled the fascicles of fibers, which, themselves, were otherwise relatively free of label, resulting in a honeycomb pattern, while glial cell bodies and processes were heavily labeled.

A similar comparison of the label over the molecular layer in the DCN at 15 and $40 \mathrm{~min}$ after injection also 

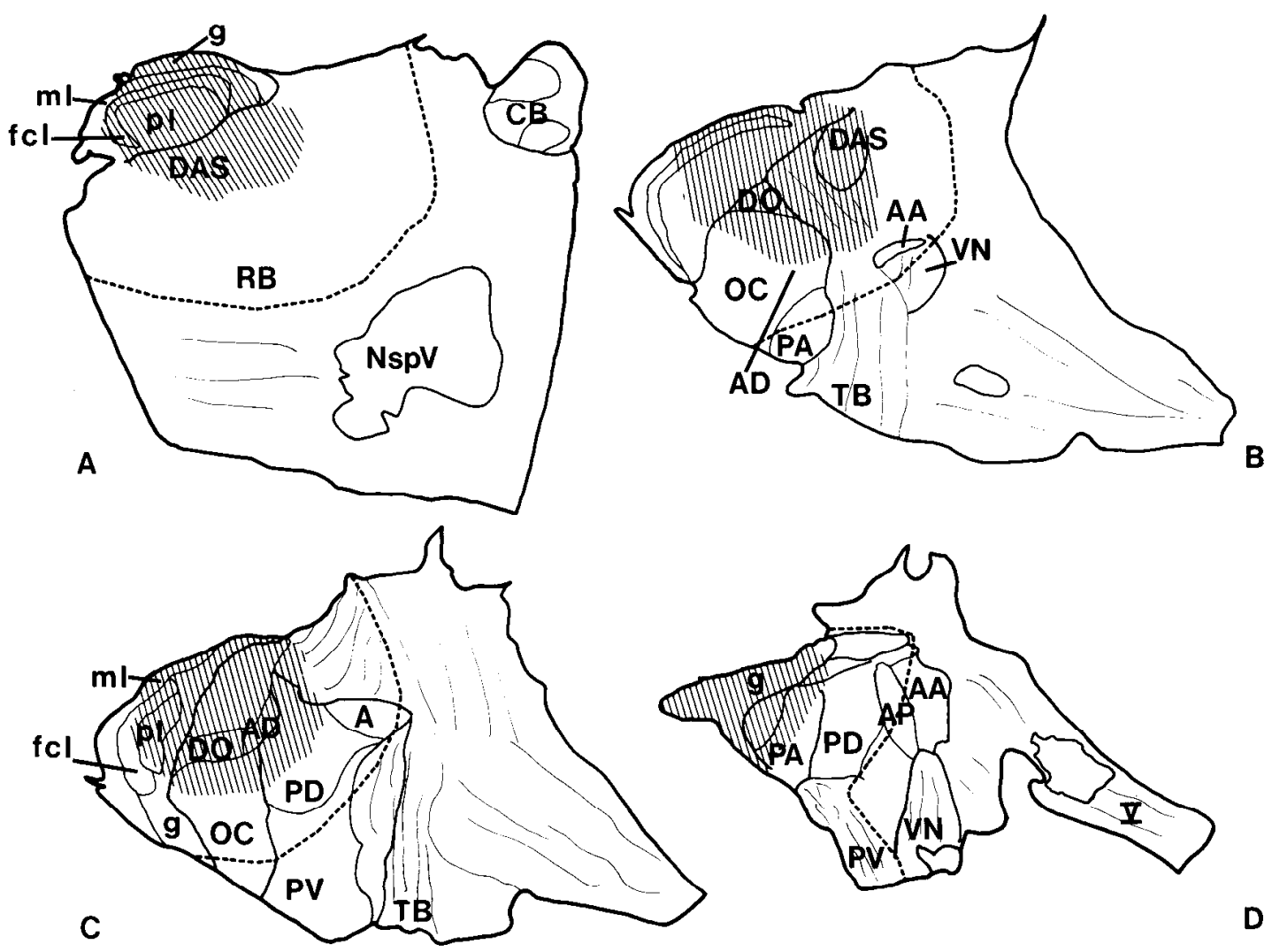

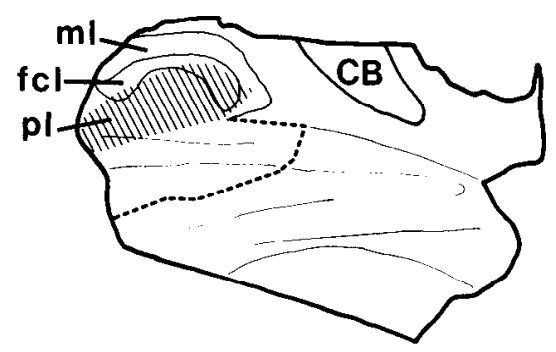

E

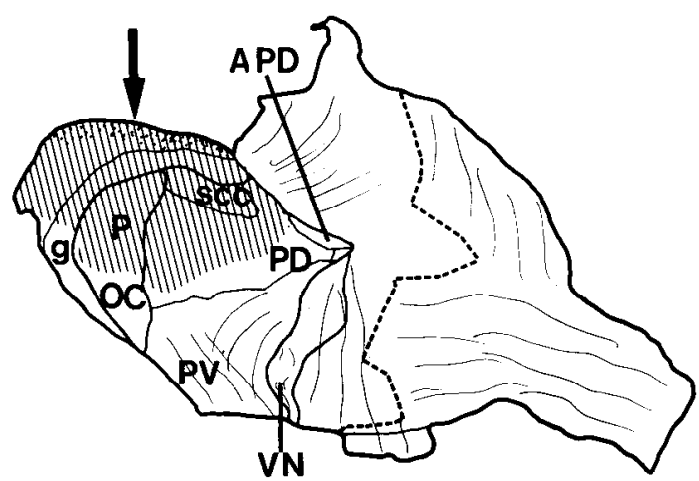

G
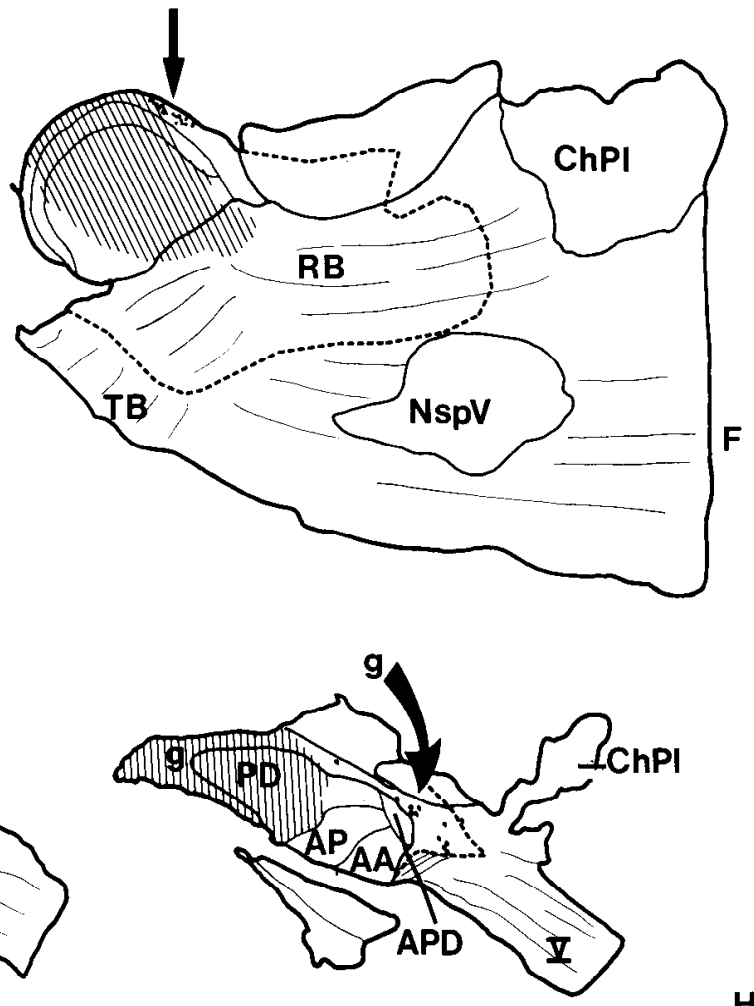

Figure 2. D-Asp injection sites in guinea pig cochlear nucleus parasagittal sections. Injection site (shading) surrounded by regions of above-background label (dashed line). $A$ to $D, \mathrm{GP} 2072380,15 \mathrm{~min}$ injection; $E$ to $H, \mathrm{GP} 4072380,40 \mathrm{~min}$ injection; $F$ to $G$, dots indicate labeled fibers in molecular layer of DCN (thick arrow); $H$, dots indicate labeled granule cell bodies in external granule cell layer (curved arrow). Three-micrometer sections; $7 \frac{1}{2}$-week exposure autoradiographs. $A, E$, most medial; $D, H$, most lateral; rostral is to the right. 


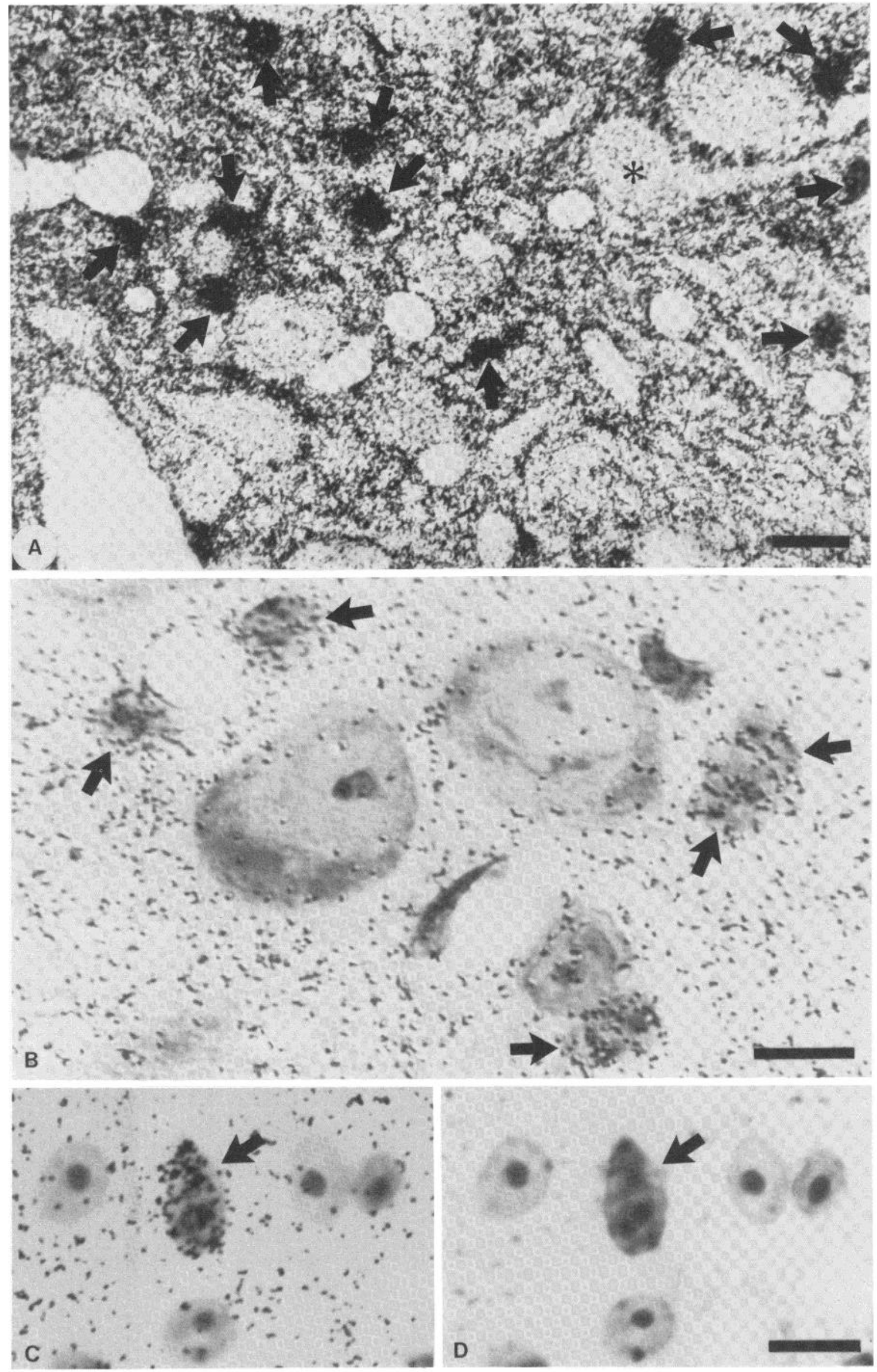

Figure 3. Labeling of neuropil and glia 15 min after injection of D-Asp. A, Labeling in PVCN with perineuronal clusters of grains, including an octopus cell (arrows indicate heavily labeled glial cell bodies). $B$, The neuropil and astrocytic somata (arrows) are heavily labeled but not large and small neuronal cell bodies. $C$ and $D$, Two micrographs in DCN at different focal planes show that the small granule cells are distinguished from labeled astrocytes (arrows) by nuclear morphology. GP2072380; 3- $\mu \mathrm{m}$ parasagittal sections; exposures for autoradiographs $A, C$, and $D$ 71/2 week; $B, 4 \mathrm{~d} ;$ scale, $10 \mu \mathrm{m}$. 

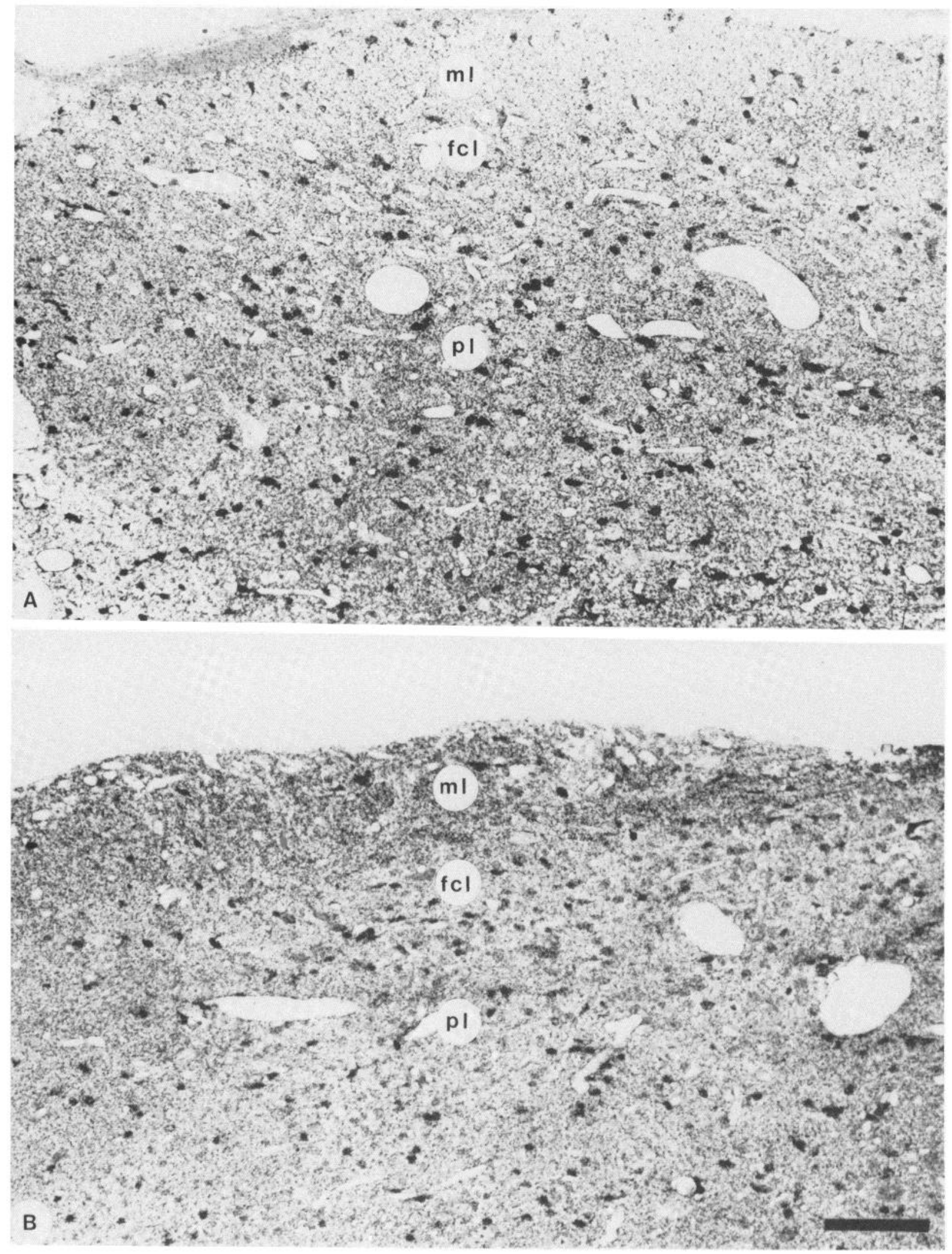

Figure 4. DCN, 15 and $40 \mathrm{~min}$ after injection of D-Asp. Labeled actrocytes appear as small dark cells scattered evenly throughout the nucleus. $A, 15$-min injection (GP2072380) with diffuse labeling of neuropil; $B$, 40-min injection (GP4072380) with label concentrated in the molecular layer $(\mathrm{ml})$, where labeled parallel fibers are evident (upper right). Seven and one-half-week exposure autoradiographs; 3 - $\mu \mathrm{m}$ parasagittal sections; scale, $100 \mu \mathrm{m}$. 

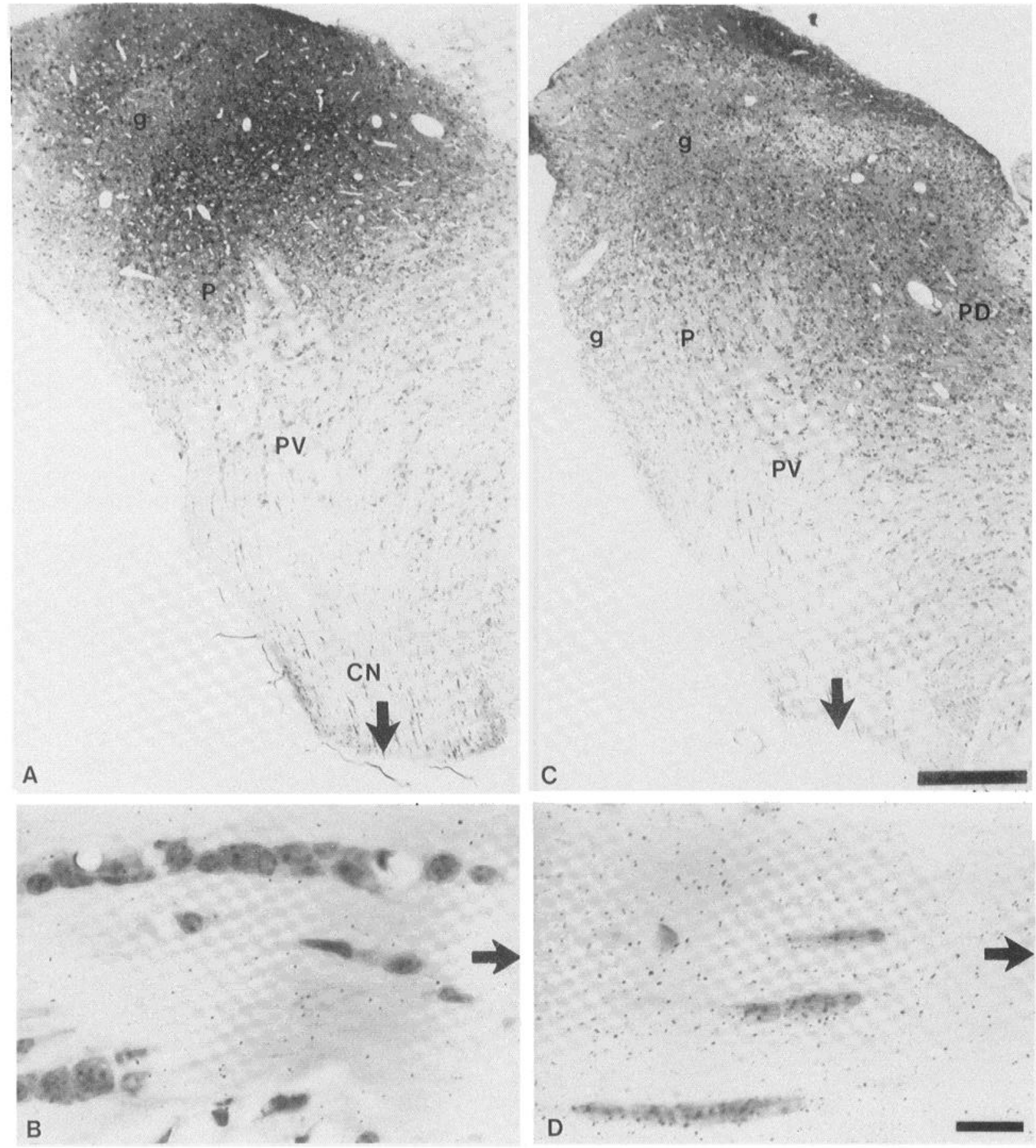

Figure 5. Ventral cochlear nucleus and cochlear nerve root $(C N) 15$ and 40 min after injection of D-Asp. $A, 15$-min injection site (GP2072380; see Fig. 2C); arrow indicates ventral direction and field shown in B. B, Fiber fascicles in the cochlear nerve root are only lightly labeled $15 \mathrm{~min}$ after injection (cut ventral stump visible on right); arrow indicates ventral direction. $C$, 40-min injection site (GP4072380; see Fig. 2G); arrow indicates ventral direction and field shown in $D$. $D$, Labeled fibers and interfascicular glia in the cochlear nerve root $40 \mathrm{~min}$ after injection (arrow, ventral is toward the right). Three-micrometer parasagittal sections; $71 \frac{12}{2}$ week exposure autoradiographs; scales $A$ and $C, 500 \mu \mathrm{m} ; B$ and $D, 20 \mu \mathrm{m}$.

provides evidence for uptake and retrograde transport of D-Asp by axons. The molecular layer contains some granule and small cell bodies and dendrites of underlying neurons but consists predominantly of parallel fibers, the axons of granule cells extending between the DCN and the external granule cell layer (Fig. 4). In contrast to the cochlear nerve fibers, the synaptic endings of the parallel fibers are very small, predominantly axodendritic, and diffusely distributed in the neuropil, where they are especially concentrated in the molecular layer of the DCN (Lorente de Nó, 1981; Kane, 1974; Mugnaini et al., 1980b). At $40 \mathrm{~min}$ after injection, there was labeling over the fibers of the molecular layer which was heavier within the injection site than in adjacent regions (Fig. $4 B$ ). Rostral to the injection, a band of prominent silver grains lay over the fibers extending from the DCN through the 
external granule cell layer over the dorsal and lateral AVCN (Fig. $2 G$ ); a few ${ }^{3} \mathrm{H}$-labeled granule cell bodies were evident in the external granule cell layer as well as in the DCN (Fig. $2 H$ ). In contrast to the 40 -min pattern, neither the label over the external granule and molecular layer nor the labeled granule cell bodies was present 15 min after injection (Fig. $4 A$ ).

Additional labeling of fibers in these experiments was found adjacent to the injection site in the trapezoid body, which contains axons projecting to and from the cochlear nucleus. Such label usually was confined to a few fibers which emerged from the center of the injection site, ran parallel to the surface of the section in a ventral direction, and entered the trapezoid body. These few fibers were covered with a heavy coat of silver grains, as if they had been diffusely filled with D-Asp (Fig. 6A). It is possible that these were fibers from neurons whose cell bodies were damaged by the injection pipette. More extensive label over fibers of the trapezoid body and other efferent pathways of the cochlear nucleus only occurred within injections whose concentration was several orders of magnitude greater than the $\mathrm{K}_{\mathrm{m}}$ for high-affinity uptake. Such injections were so radioactive that the features of neuropil labeling were obscured in the injection site. However, the dense labeling of fibers in the trapezoid body was not observed to migrate to the superior olivary complex within the 15 - to 40 -min survival time.

Later localization of $D$-Asp in situ. The results described above suggest that the D-Asp enters glia and axon terminals initially and migrates retrogradely in the cochlear nerve and parallel fibers of the DCN. Longer survival times should allow the marker to migrate to the cell bodies of the spiral ganglion in the cochlea (Fig. 7A, $S G$ ) and the granule cells within the cochlear nucleus (Fig. $7 B, g)$. Other types of neurons should not be labeled by this process.

The locations of extrinsic neurons projecting to the cochlear nucleus in addition to the spiral ganglion are shown in Figure $7 A$. If most of the cochlear nucleus were exposed to a suitable, nonspecific tracer, all of the extrinsic neurons should become labeled. For example, when HRP was injected into the nucleus, neurons were labeled
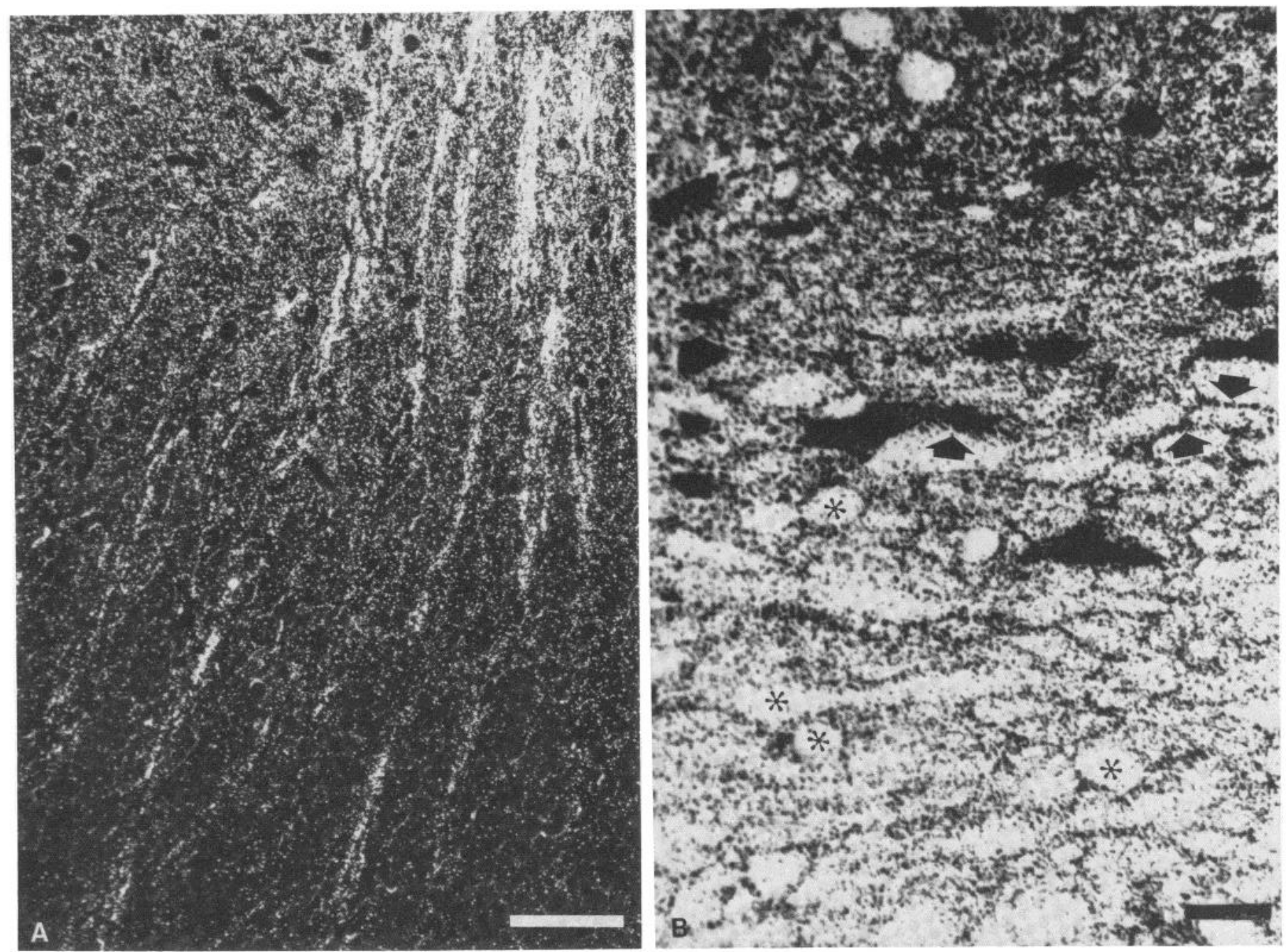

Figure 6. Trapezoid body and dorsal acoustic stria labeling $15 \mathrm{~min}$ after D-Asp injection. $A$, Dark-field micrograph of densely labeled fibers running from injection site in the cochlear nucleus (above) ventrally into the trapezoid body (section between those in Fig. 2, $B$ and $C$ ). $B$, bright-field micrograph of label surrounding fascicles of axons in the dorsal acoustic stria adjacent to the cochlear nucleus (above); it appears that glia and their processes (arrows) are labeled while the axons (*) are not (section shown in Fig. $2 A, D A S)$. GP2072380; 3- $\mu \mathrm{m}$ parasagittal sections; 71/2-week exposure autoradiographs; scale A, $100 \mu \mathrm{m} ; B, 20 \mu \mathrm{m}$. 


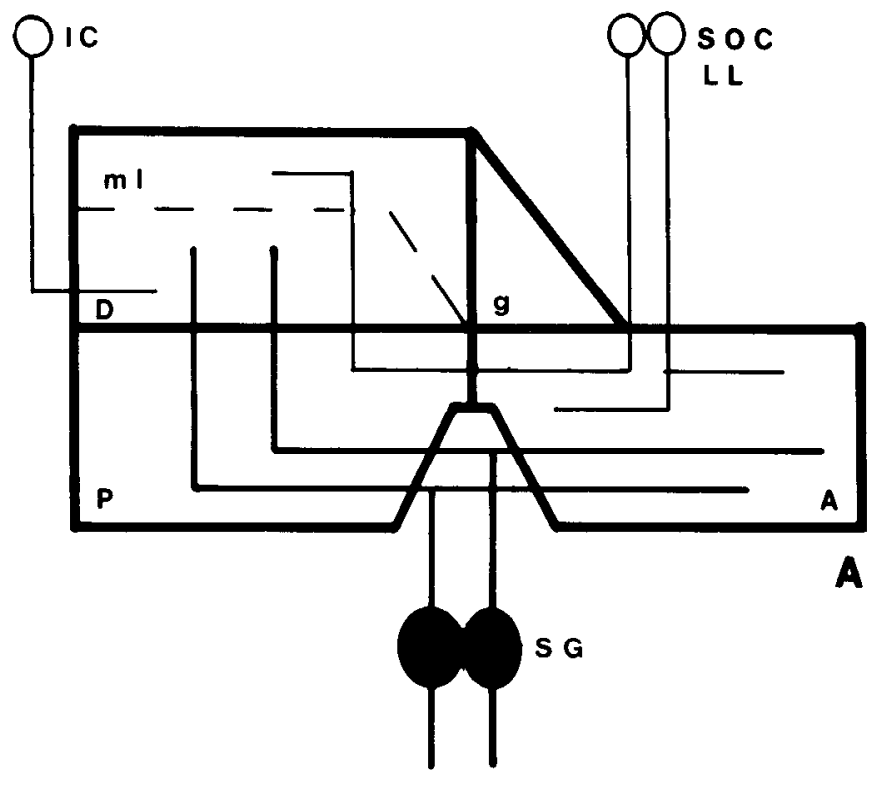

A

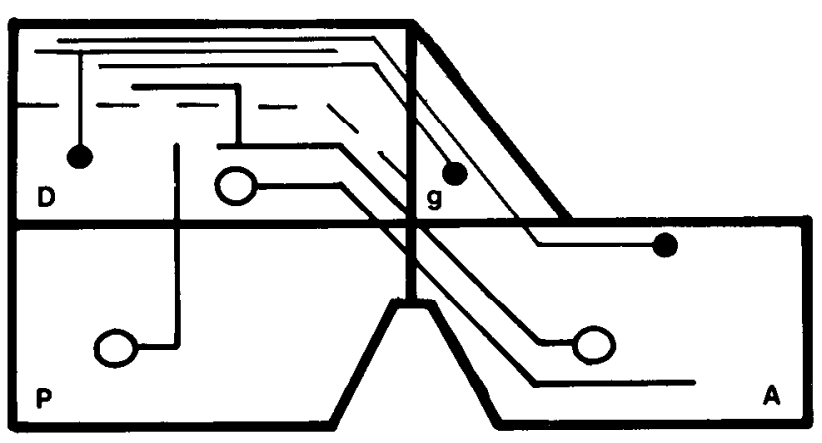

Figure 7. Diagrams to show the inputs $(A)$ and intrinsic connections $(B)$ of the cochlear nucleus in a parasaggital scheme. Neurons labeled by D-Asp are indicated in black.

via retrograde axonal transport in the superior olivary complex, the inferior colliculus, and the spiral ganglion (not illustrated) (see also Kane, 1976; Ruggero et al., 1982; Oliver et al., 1981). In contrast, when D-Asp was injected, the only extrinsic neurons labeled were those of the spiral ganglion (Fig. 8). Six hours or more after injection of D-Asp, most label was over the spiral ganglion cells and the portion of the cochlear nerve proximal to the ganglion. In $1-\mu \mathrm{m}$-thick plastic sections prepared for high resolution light autoradiography, it is clear that all visible ganglion cells were labeled.

As with the shorter survival times, injections of D-Asp at concentrations several orders of magnitude above the $\mathrm{K}_{\mathrm{m}}$ for its high-affinity uptake produced some labeling of fiber tracts and neuropil which contain the projection pathways from the cochlear nucleus. On the other hand, an injection of D-Asp in the inferior colliculus produced no labeling of the cochlear nucleus cells.

The locations of intrinsic neurons in the cochlear nucleus, including the granule cells, are shown in Figure $7 B$.
Several types of intrinsic neurons send axons from the AVCN, PVCN, and external granule cell layer to the DCN. Thus, a small injection of a nonspecific marker, WGA-HRP, into the DCN labeled granule cells in the external granule layer as well as stellate and elongate neurons in the AVCN and in the anterior PVCN (Fig. $9 B$ ). The morphology of each of these cell types was described in prior studies of the cochlear nuclues (see Brawer et al., 1974). In contrast, similar small injections of D-Asp, confined to the DCN, labeled only one of these cell types, the granule cell (Fig. $9 \mathrm{C}$ ). In these experiments most of the label in the injection site within the DCN was confined to the molecular layer, which contains the axons (parallel fibers) of the granular cells (Fig. 9A). In contrast to the appearance of the injection site 15 to 40 min after injection, where the glial cell bodies were hcavily labeled, at these long survival times much of the label in glial somata was lost (compare Figs. 4 and $9 A$ ). Labeled granule cell perikarya are located millimeters rostral to the injection site but only within the external granule cell layer, where the marker could reach them by retrograde migration of $\mathrm{D}$-Asp through the axons.

\section{Discussion}

The following hypotheses can be proposed on the basis of the present findings. First, D-Asp injected into the cochlear nucleus is initially taken up by astrocytes and by the synaptic endings of cochlear nerve fibers and granule cells by a high-affinity transporter. Second, the same endings that lake up D-Asp release it during synaptic transmission. Third, D-Asp subsequently migrates by retrograde axonal transport from the synaptic endings to the perikarya of spiral ganglion cells in the cochlea and of granule cells in the cochlear nucleus. Finally, the spiral ganglion cells and granule cells may use L-Glu/LAsp as a synaptic transmitter.

We first discuss the evidence for these hypolheses provided by the in vitro and in situ studies on uptake and release from axonal endings and selectivity of the autoradiographic labeling for specific cell types. We next discuss the evidence that L-Glu/L-Asp are transmitters in the cochlear nucleus and their possible role in signal processing in the auditory system.

\section{Evidence that $D$-Asp is taken up and released from axonal endings}

In vitro studies. The present results suggest that soon after uptake into the cochlear nucleus, D-Asp is present in axonal endings. Evidence for this conclusion is provided by studies of $\mathrm{D}$-Asp release in vitro. There was a marked release of D-Asp on electrical stimulation in each division of the cochlear nucleus which had previously laken up the amino acid. This release is abolished by reducing the concentration of $\mathrm{Ca}^{2+}$ ions in the medium. Since the synaptic release of transmitters requires the depolarization of axons and the presence of $\mathrm{Ca}^{2+}$ ions in the extracellular fluids (see Rubin, 1974), these findings suggest that the D-Asp was released from axon endings. Further support for this conclusion is provided by previously reported findings. Uptake of both L-Glu and LAsp is apparently mediated by two kinetically distinct 

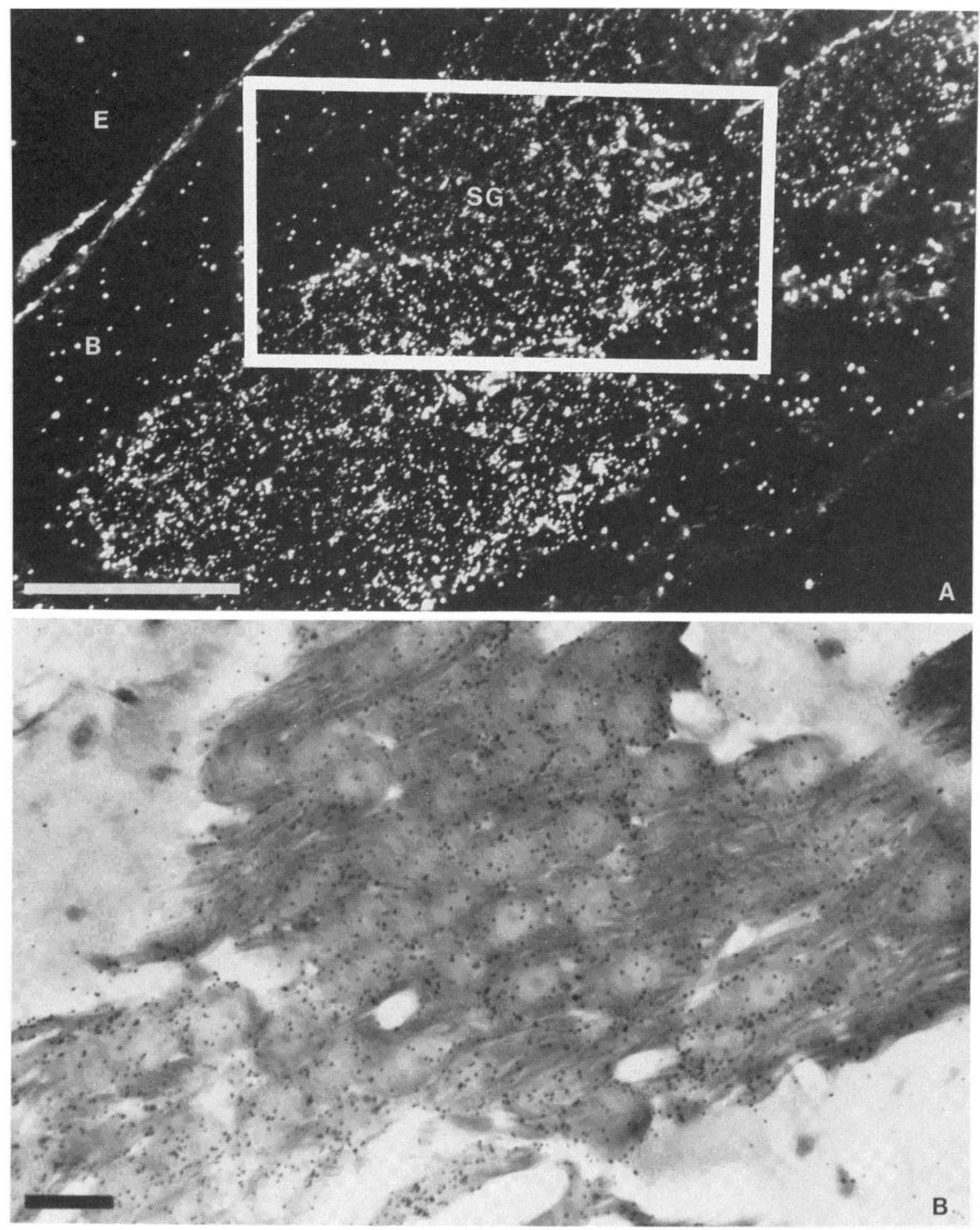

Figure 8. Label in spiral ganglion of cochlea $2 \mathrm{~d}$ after injection of D-Asp into cochlear nucleus. $A$, Dark-field micrograph shows relative labeling of ganglion $(S G)$, bone $(B)$, and emulsion $(E)$. B, Bright-field micrograph from boxed region in A; many fibers and every ganglion cell are labeled. C1060480; 4- $\mu \mathrm{m}$ section; 23 -week exposure autoradiographs; scales $A, 100 \mu \mathrm{m} ; B, 20 \mu \mathrm{m}$.

Figure 9. Labeled granule cells in cochlear nucleus 1 to $2 \mathrm{~d}$ after injection of D-Asp compared with WGA-HRP-labeled neurons from a comparable injection. $A$, Dark-field micrograph of labeled neuropil of the molecular layer after a small injection in DCN $B$, Bright-field micrograph of labeled granule cells in the external granule layer (above) and stellate neurons (arrow) in AVCN after injection of WGA-HRP in DCN. $C$, D-Asp injections in DCN (shown in $A$ ), by comparison, result only in labeled granule cells in the external granule layer. $D$, Labeled granule cells in the external granule layer (arrows) but no marked neurons except two granule cells in the underlying AVCN (at left) after a large D-Asp injection involving the whole cochlear nucleus. $A$ and $C$, 30 $\mu \mathrm{m}$ sections, 3-month exposure autoradiographs, C1111880; $B, 50-\mu \mathrm{m}$ section, tetramethyl-benzidine reaction, C1111880; $D$, 30- $\mu \mathrm{m}$ section, 31/2-month exposure autoradiograph, C1102980. Scale $A, B$, and $D, 100 \mu \mathrm{m} ; C, 50 \mu \mathrm{m}$. 

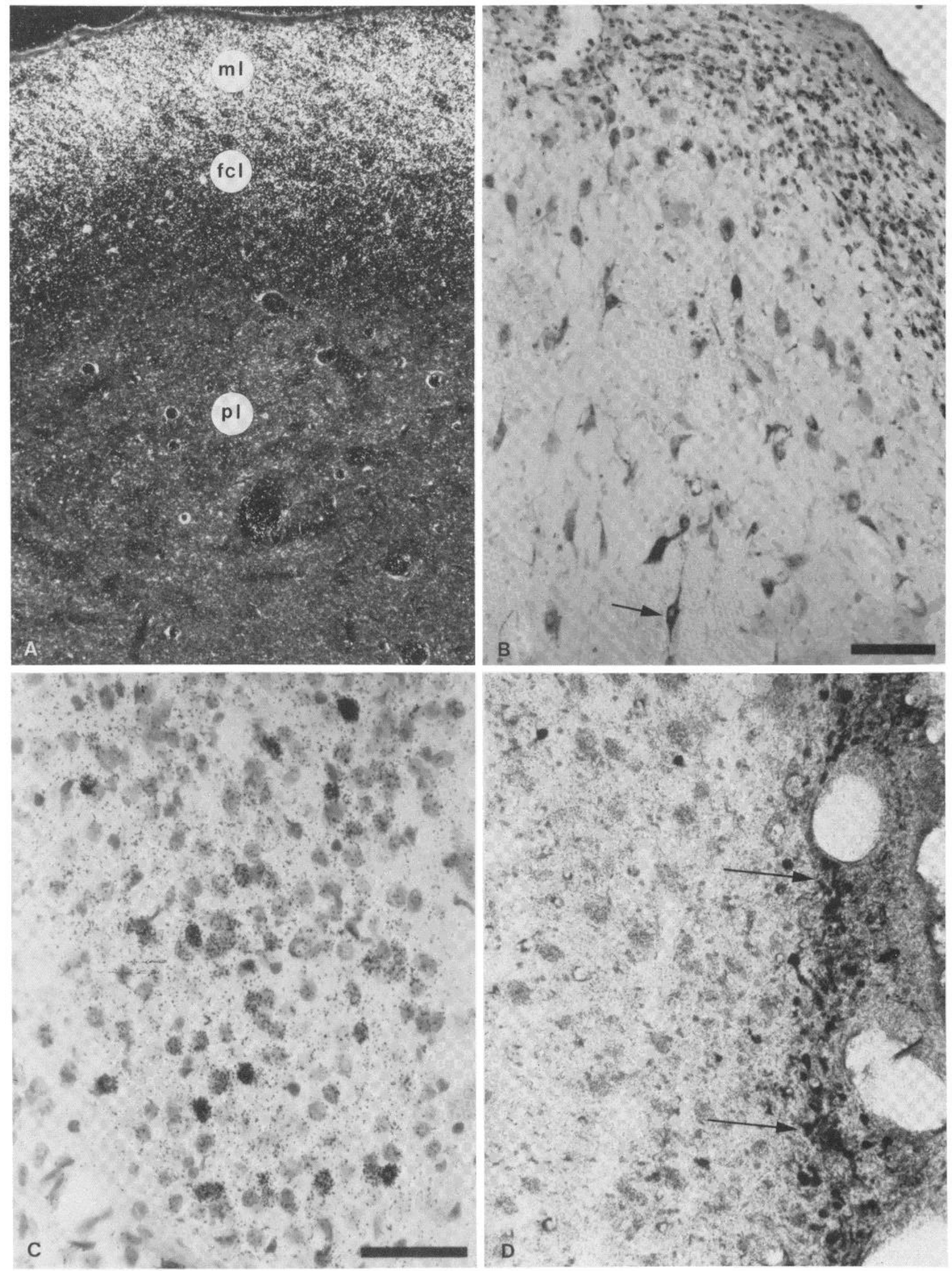
systems-a low-affinity transporter, with a $\mathrm{K}_{\mathrm{m}}$ in the $10^{-3} \mathrm{M}$ range, and a high-affinity transporter, with a $\mathrm{K}_{\mathrm{m}}$ in the $10^{-5} \mathrm{M}$ range (Logan and Snyder, 1972; Balcar and Johnston, 1972, 1973). Uptake of D-Asp appears to be mediated by the high-affinity transporter (Davies and Johnston, 1976), which has been associated with glia and a subpopulation of axon endings derived from whole brain (see Johnson, 1978). That D-Asp gains access to axonal endings is indicated by its high-affinity uptake into synaptosomal fractions (Davies and Johnston, 1976; Takagaki, 1978) and by its $\mathrm{Ca}^{2+}$-dependent release from several tissues (Davies and Johnston, 1976; Malthe-Sorenssen et al., 1979, 1980; Beaudet et al., 1981).

In situ studies. Autoradiographic observations following injections of D-Asp in the cochlear nucleus also provide evidence for the uptake of this amino acid by synaptic endings. The earliest labeling observed appeared over structures in the neuropil resembling axonal endings. This is most evident in the case of the perisomatic structures typical of the large cochlear nerve endings, such as the boutons or end bulbs visible in the light microscope. However, without electron microscopic autoradiography one cannot tell if there is labeling of the small endings of the cochlear nerve or of the parallel fibers. Glial processes surrounding endings might also be labeled. However, the progressive change, with time, in the labeling pattern over fibers and cell bodies supports the interpretation that $\mathrm{D}$-Asp is transported retrogradely in the fibers of the cochlear nerve and the granule cells.

The autoradiographic results followed injections of amino acid at a concentration near the $K_{m}$ for the highaffinity uptake of $\mathrm{D}$-Asp determined in vitro (Davies and Johnston, 1976). It is reasonable to presume that the same uptake mechanism operates in situ in the present experiments and that it is primarily responsible for the present labeling of axonal endings. Consistent with this assumption is the presence of heavily labeled astrocytes 15 min after the injections, for these cells are also known to have the high-affinity transporter for $\mathrm{L}-\mathrm{Glu} / \mathrm{L}-\mathrm{Asp}$. Since the glial cells gradually lose their label over $48 \mathrm{hr}$, it is possible that D-Asp is slowly metabolized or lost from the glial compartment.

\section{Selectivity of $D$-Asp labeling}

Several studics provide evidence that certain ${ }^{3} \mathrm{H}$-amino acids can label specific cell types thought to use amino acid transmitters. For example, injections of $\left[{ }^{3} \mathrm{H}\right] \mathrm{GABA}$ into the cerebellar cortex selectively label intrinsic neurons thought to utilize GABA, such as stellate, basket, and Golgi type II cells (Höfelt and Ljungdahl, 1970, 1972; Kelly et al., 1975; Kelly and Dick, 1976). Electron microscopic autoradiography showed sclective labeling of synaptic endings of the type that belong to these neurons as well as to Purkinje cells, which are also thought to be GABAergic. There is some evidence that D-Asp labels specific types of cells which use L-Glu/LAsp as a synaptic transmitter. In the cerebellar cortex, for example, injections of D-Asp selectively labeled granule cells and parallel fibers, which use L-Glu as a transmitter (Young et al., 1974; Chujo et al., 1975; Sandoval and Cotman, 1978), but not the other neurons which use GABA (Oliver et al., 1981; S. J. Potashner et.al., manu- script in preparation). D-Asp labeling has also been reported to be confined to ganglion cells in the pigeon retina (Beaudet et al., 1981), to neurons in layers 1, 5, and 6 of neocortex (Streit, 1980; Baughman and Gilbert, 1981; LeVay and Sherk, 1981; Rustioni and Cuenod, 1982), in the thalamus (Streit, 1980), in the spinal cord (Rustioni and Cuenod, 1982), and in the hippocampus (Storm-Mathisen, 1981). However, the correlations between D-Asp labeling and morphologic or physiologic types of neurons have not been fully established. The present work demonstrates selective labeling of three specific types of neurons identified a priori on morphologic grounds: the granule cells of the cochlear nucleus and the type I and II spiral ganglion cells (see Jones et al., 1982; D. R. Jones et al., manuscript in preparation). This information should allow us to establish correlations between the morphologic and physiologic properties of specific types of neurons and their transmitter chemistry.

It has been suggested that the retrograde axonal transport of $\mathrm{D}$-Asp could serve as a specific criterion for tracing the connections of neurons using L-Glu/L-Asp as a transmitter (Streit and Cuenod, 1979). In keeping with this suggestion, several investigations show retrograde labeling of certain projections with D-Asp in the visual (Beaudet et al., 1981; Baughman and Gilbert, 1981) and striatal (Streit, 1980; LeVay and Sherk, 1981) pathways. The present findings demonstrate selective D-Asp labeling of one projection with cell bodies extrinsic to the cochlear nucleus and also of an intrinsic pathway. The observations are consistent with a process of retrograde axonal transport in both of these pathways. In the cochlear nerve root, $15 \mathrm{~min}$ after an injection there was sparse, but significant labeling of fiber fascicles, while $40 \mathrm{~min}$ after injection the density of label increased markedly in the nerve root. This temporal progression of labeling density is consistent with a retrograde migration of $\mathrm{D}$ Asp in the cochlear nerve axons. In the molecular and external granular layers, the labeling pattern and its temporal progression are also consistent with retrograde axonal transport of $\mathrm{D}$-Asp by the parallel fibers of granule cells.

In the cochlear nerve root, two compartments can be recognized in the light microscope. By far the larger part of the root consists of tightly packed fascicles of cochlear nerve fibers, the fascicular compartment. Embedded between these fascicles are narrow strands of glial and occasional neuronal cell bodies and neuropil, which constitute the interfascicular compartment. At 15 min after injection of $\mathrm{D}$-Asp, labeling is practically confined to the fascicular compartment. At $40 \mathrm{~min}$ after an injection, both compartments are labeled, although by far the greater density of labeling covers the fiber fascicles, where the grains line up in strands. By $6 \mathrm{hr}$ after an injection, the labeling has largely disappeared from the interfascicular compartment and from the glial cell bodies in general, while the cochlear nerve fibers are still intensely labeled. These labeling patterns and their temporal permutations are consistent with a process of retrograde axonal transport in the cochlear nerve. The appearance of label over interfascicular glial cells might be a secondary phenomenon. This could result from diffusion of $\mathrm{D}$-Asp from the fibers into the interfascicular 
space, where it could be taken up by glial processes. A second possibility is that D-Asp might diffuse from the injection site through the extracellular space into the nerve root, where it might gain access to glial cells. This second process, if it operates at all, would not explain the labeling pattern in the cochlear nerve root. Had extraneuronal diffusion played a major role in these experiments, a different labeling pattern might have been expected, similar to that seen in the dorsal acoustic stria where it merges with the injection site. There the labeling pattern suggests that the injection has entered the interfascicular compartment without gaining access to the axons. This labeling pattern is very different from that of the cochlear nerve root, where retrograde axonal transport presumably occurs. Finally, the very specificity of the labeling of cell types at longer survival times argues against a non-neuronal migration of D-Asp.

There is little or no evidence of transmitter-specific anterograde axonal transport of D-Asp in the present study. If that had been the case, we would have expected to see selective labeling of specific efferent pathways from the cochlear nucleus. Moreover, these same pathways should have been retrogradely labeled by D-Asp injected in the inferior colliculus. The apparent examples of anterograde transport of D-Asp in the trapezoid body and other efferent pathways occurred in cases in which there was evidence of fiber damage and in which high concencentrations of D-Asp were injected. These examples of anterograde transpori might be due to processes not related to the chemistry of the transmitter.

\section{$L$-Glu and $L$-Asp as transmitters in the cochlear nucleus}

The present evidence suggests that $\mathrm{L}-\mathrm{Glu} / \mathrm{L}$-Asp is used by the cochlear nerve and by granule cells as a transmitter in the cochlear nucleus. Considerable evidence from several other systems suggests that D-Asp can serve as a marker for several neuron types which probably use L-Glu/L-Asp as their transmitter. For example, injection of D-Asp into the cerebellar cortex labels cerebellar granule cells (Oliver et al., 1981) and cells in the inferior olive (Wiklund et al., 1982), the presumed source of climbing fibers innervating the cerebellar cortex. Independent biochemical evidence suggests that these cell types use L-Glu/L-Asp as their transmitters (Young et al., 1974; McBride et al., 1976a, b; RofflerTarlov and Sidman, 1978; Sandoval and Cotman, 1978; Nadi et al., 1977; McBride et al., 1978; Wiklund et al., 1982). Similarly, injection of D-Asp into the striatum labels a subpopulation of neurons in the cerebral cortex which project to the striatum (Streit, 1980; LeVay and Sherk, 1981) and are believed to use L-Glu as their transmitter (Divac et al., 1977; McGeer et al., 1977; Kim et al., 1977; Fonnum et al., 1981). In the present experiments, injection of D-Asp into the cochlear nucleus labels primary auditory neurons, which suggests that L-Glu/LAsp may be their transmitter. Corroboration comes from biochemical and neuropharmacologic studies which provide convincing evidence that $\mathrm{L}$-Glu/L-Asp may be the cochlear nerve transmitter (see beginning of report for references).

It is, perhaps, somewhat unexpected that injection of
D-Asp into the cochlear nucleus also labels granule cells. At present, this is the only direct evidence that these neurons may use L-Glu/L-Asp as their transmitter. However, the presence in the cochlear nucleus of noncochlear endings that utilize L-Glu/L-Asp is suggested by experiments in which the cochlear nerve was destroyed. If the cochlear nerve were the only source of endings utilizing $\mathrm{L}$-Glu/L-Asp in the nucleus, its destruction should produce large deficits in L-Glu or L-Asp levels and a complete decrement in the release of these putative transmitters. However, in one study, after this lesion no deficits were reported in L-Glu or L-Asp levels in the DCN and only moderate deficits in the ventral cochlear nucleus (Wenthold, 1978). Furthermore, this lesion produced an incomplete decrement in the release of L-Glu and L-Asp from the whole cochlear nucleus (Wenthold, 1979; Canzek and Reubi, 1980). These findings could be explained if the total levels of these compounds in the DCN contributed by the cochlear nerve were small compared with those contributed by granule cells.

\section{Functional significance of the findings}

In the cochlear nucleus the pattern of D-Asp labeling suggests that many, if not all, of the big cochlear nerve endings around the large perikarya (including bushy cells and octopus cells) in the ventral cochlear nucleus could utilize L-Glu/L-Asp. Electron microscopic observations of this same population of endings show that they have a characteristic fine structure (Tolbert and Morest, 1982a, b; Tolbert et al., 1982; Kane, 1973; Caspary, 1973). These synaptic endings are characterized by large spherical vesicles, a widened synaptic cleft, and a pronounced asymmetry of the synaptic membrane densities. The synaptic complexes of the large end bulbs in the rostral AVCN have the same morphologic characteristics (Cant and Morest, 1979a, b). There is compelling electrophysiologic evidence that these particular end bulbs make excitatory synapses with bushy cells (Bourk, 1976; Pfeiffer, 1966). On this basis we may postulate that the large endings of the cochlear nerve make excitatory synapses in the cochlear nucleus by means of type I synaptic complexes that utilize L-Glu or L-Asp as a transmitter.

This hypothesis must be qualified, in that there is always a possibility that L-Glu could produce an inhibitory effect as well as an excitatory one, depending on the characteristics of the postsynaptic response. There is evidence that L-Glu could produce both an EPSP and an IPSP in some hippocampal pyramidal cells (Nicoll and Alger, 1981). If synapses using L-Glu/L-Asp are strictly excitatory, it could explain some of the electrical response properties of neurons in the cochlear nucleus. For example, the primary-like response pattern of bushy cells in the AVCN typically preserves the time pattern of the response of the cochlear nerve to acoustic stimulation (Rose et al., 1973; Bourk, 1976). Presumably, this depends on prepotent excitatory input from the large end bulbs of the cochlear afferents, which provide for a high degree of synaptic security-in fact, a one-to-one input-output signal transmission ratio at this synapse, i.e., a faithful preservation of the cochlear output. This feature of the response would be a function of the morphology of the synaptic ending and the action of the synaptic transmit- 
ter. For another example, the octopus cells in PVCN typically transform the signal from the cochlear nerve. Whereas the cochlear nerve fibers typically respond for the duration of an acoustic stimulus, octopus cells may respond only at the stimulus onset and remain relatively quiet for the rest of the stimulus duration (Godfrey et al., 1975a). The tendency of the onset responses of these cells to occur consistently at the minimum latency may reflect. the spatial convergence of many different axons with excitatory synapses. These features could be explained in terms of the spatial arrangement of the many large type I endings from the cochlear nerve (Morest et al., 1973) and the chemical properties of transmission at the synapses.

If L-Glu/L-Asp serves as a transmitter for granule cells in the DCN, as the present findings suggest, then these neurons may function as excitatory interneurons in the local circuits of the cochlear nucleus. For example, a large number of granule cells would project to individual fusiform cells in the DCN by way of parallel fibers in the molecular and fusiform cell layers (Kane, 1974). This arrangement might account for the relatively high level of spontaneous activity and complex configurations of excitatory and inhibitory response areas observed in fusiform cells (Evans and Nelson, 1973a; Young and Brownell, 1976). It might also form part of a feed-forward loop which consists of an excitatory input from the cochlear nerve common to both granule and fusiform cells. Such a loop could contribute to generation of the progressively increasing excitatory activity characteristic of the buildup and pauser types of responses observed in the peristimulus time histograms which have been attributed to fusiform cells (Kane, 1974; Godfrey et al., 1975b).

The microcircuitry in the DCN has a certain similarity to that of the cerebeller cortex (Lorente de Nó, 1933, 1981; Mugnaini et al., 1980a). However, the arrangement of the granule and fusiform cells in the DCN is different from that of the granule and Purkinje cells in the cerebellar cortex. The excitatory input from the climbing fiber is not common to both granule and Purkinje cells. Although cerebellar granule cells may also use L-Glu as an excitatory transmitter at synapses with Purkinje cells, the latter receive excitatory inputs from two separate sources, climbing and parallel fibers. The mossy fiber input is to the granule cell, which in turn projects to the Purkinje cell. Moreover, the climbing fiber and granule cell synapses have a different arrangement on the Purkinje cell than do the cochlear and parallel fiber synapses on the fusiform cell of the DCN. In any case, in the cochlear nucleus, it appears that excitatory as well as inhibitory local circuits could play a role in determining the response properties of fusiform cells (Kane, 1974; Godfrey et al., 1975; Young, 1980; Evans and Nelson, 1973b).

'The identification of the neurotransmitters at particular synaptic junctions may help to explain how the different kinds of synaptic organization in the subdivisions of the cochlear nucleus relate to the processing of auditory information. The present study suggests that cochlear nerve fibers may use L-Glu/L-Asp as a transmitter and that this may be responsible, in part, for certain excitatory responses in the cochlear nucleus to the eighth nerve activation. On the other hand, the different cell types, arrangements of synaptic junctions, postsynaptic receptor properties, local circuits, and long connections all may shape the different types of responses to sound displayed by neurons of the cochlear nucleus. The present study shows that D-Asp may be a useful marker for local circuit neurons which utilize LGlu/L-Asp. The presence of different transmitters in different types of local circuit neurons is undoubtedly an important aspect of synaptic organization which helps distinguish the processes used by the subdivisions of the cochlear nucleus to transmit information about sound.

\section{References}

Anden, N. E., K. Fuxe, and K. Lavesson (1966) Effect of large mesencephalic-diencephalic lesions on the noradrenalin, dopamine and 5-HT neurons of the central nervous system. Experientia 22: 842-843.

Balcar, V. J., and G. A. R. Johnston (1972) The structural specificity of the high affinity uptake of L-glutamate and Laspartate by rat brain slices. J. Neurochem. 19: 2657-2666.

Balcar, V. J., and G. A. R. Johnston (1973) High affinity uptake of transmitters: Studies on the uptake of L-aspartate, GABA, L-glutamate and glycine in cat spinal cord. J. Neurochem. 20: 529-539.

Baughman, R. W., and C. D. Gilbert (1981) Aspartate and glutamate as possible neurotransmitters in the visual cortex. Neuroscience 4: 427-439.

Beaudet, A., A. Burkhalter, J. C. Reubi, and M. Cuenod (1981) Selective bidirectional transport of $\left({ }^{3} \mathrm{H}\right)$ D-aspartate in the pigeon retino-tectal pathway. Neuroscience 6: 2021-2034.

Bourk, T. R. (1976) Electrical responses of neural units in the anteroventral cochlear nucleus of the cat. Doctoral dissertation, M.I.T., Cambridge, MA.

Brawer, J. R., D. K. Morest, and E. C. Kane (1974) The neuronal architecture of the cochlear nucleus of the cat. J. Comp. Neurol. 155: 251-299.

Cant, N. B., and D. K. Morest (1979a) Organization of the neurons in the anterior division of the anteroventral cochlear nucleus of the cat. Light microscopic observations. Neuroscience 4: 1909-1923.

Cant, N. B., and D. K. Morest (1979b) The bushy cells in the anteroventral cochlear nucleus of the cat. A study with the electron microscope. Neuroscience 4: 1925-1945.

Canzek, V., and J. C. Reubi (1980) The effect of cochlear nerve lesion on the release of glutamate, aspartate, and GABA from cat cochlear nucleus, in vitro. Exp. Brain Res. 38: 437-441.

Caspary, D. M. (1973) The ultrastructure of synaptic endings in the globular and multipolar cell areas of the kangaroo rat ventral cochlear nucleus. Anat. Rec. 175: 284-285.

Caspary, D. M., D. C. Havey, and C. L. Faingold (1981) Glutamate and aspartate: Alteration of thresholds and response patterns of auditory neurons. Hear. Res. 4: 325-333.

Chujo, T., Y. Yamada, and C. Yamamoto (1975) Sensitivity of Purkinje cell dendrites to glutamic acid. Fxp. Brain Res. 23: 293-300.

Comis, S. D., and P. S. Guth (1974) The release of ACh from the cochlear nucleus upon stimulation of the crossed olivocochlear bundle. Neuropharmacology 13: 633-641.

Cowan, W. M., D. I. Gottlieb, A. E. Hendrickson, J. L. Price, and T. A. Woolsey (1972) The autoradiographic demonstration of axonal connections in the central nervous system. Brain Res. 37: 21-51.

Davies, W. E. (1975) The distribution of GABA transaminasecontaining neurones in the cat cochlear nucleus. Brain Res. 83: $27-33$.

Davies, W. E. (1977) GABA'ergic innervation of the mammalian 
cochlear nucleus. Colloques. Inst. Natl. Sante Rech. Med. 68: 155-164.

Davies, L. P., and G. A. R. Johnston (1976) Uptake and release of $\mathrm{D}$ - and L-aspartate by rat brain slices. J. Neurochem. 26: 1007-1014.

Divac, I., F. Fonnum, and J. Storm-Mathisen (1977) High affinity uptake of glutamate in terminals of corticostriatal axons. Nature 266: 377-378.

Droz, B. (1975) Autoradiography as a tool for visualizing neurons and neuronal processes. In The Use of Axonal Transport for Studies of Neuronal Connectivity, W. M. Cowan and M. Cuenod, eds., pp. 128-154, Elsevier, Amsterdam.

Evans, E. F., and P. G. Nelson (1973a) The responses of single neurones in the cochlear nucleus of the cat as a function of their location and the anaesthetic state. Exp. Brain Res. 17: 402-427.

Evans, E. F., and P. G. Nelson (1973b) On the functional relationship between the dorsal and ventral divisions of the cochlear nucleus of the cat. Exp. Brain Res. 17: 428-442.

Fisher, S. K., and W. E. Davies (1976) GABA and its related enzymes in the lower auditory system of the guinea pig. J. Neurochem. 27: 1145-1155.

Fonnum, F., J. Storm-Mathison, and I. Divac (1981) Biochemical evidence for glutamate as neurotransmitter in corticostriatal and corticothalamic fibers in rat brain. Neuroscience 6: $863-873$.

Fuxe, K. (1965) Evidence for the existence of monoamine neurons in the CNS. IV: Distribution of monoamine nerve terminals in the CNS. Acta. Physiol. Scand. 64(Suppl. 247): 3785.

Godfrey, D. A., N. Y. S. Kiang, and B. E. Norris (1975a) Single unit activity in the posteroventral cochlear nucleus of the cat. J. Comp. Neurol. 162: 247-268.

Godfrey, D. A., N. Y. S. Kiang, and B. E. Norris (1975b) Single unit activity in the dorsal cochlear nucleus of the cat. J. Comp. Neurol. 162: 269-284.

Godfrey, D. A., A. D. Williams, and F. M. Matschinsky (1977a) Quantitative histochemical mapping of enzymes of the cholinergic system in cat cochlear nucleus. J. Histochem. Cytochem. 25: 397-416.

Godfrey, D. A., J. \. Carter, S. J. Berger, O. H. Lowry, and F. M. Matschinsky (1977b) Quantitative histochemical mapping of candidate transmitter amino acids in cat cochlear nucleus. J. Histochem. Cytochem. 25: 417-431.

Godfrey, D. A., J. A. Carter, O. H. Lowry, and F. M. Matschinsky (1978) Distribution of gamma-aminobutyric acid, glycine, glutamate and aspartate in the cochlear nucleus of the rat. J. Histochem. Cytochem. 26: 118-126.

Godfrey, D. A., J. L. Park, J. R. Rabe, J. D. Dunn, J. T. Smith, and C. D. Ross (1981) Quantitative evaluation of centrifugal cholinergic pathways to the rat cochlear nucleus. Soc. Neurosci. Abstr. 7: 56.

Hanker, J. S., P. E. Yates, C. B. Metz, and A. Rustioni (1977) A new specific, sensitive and non-carcinogenic reagent for the demonstration of horseradish peroxidase. Histochem. J. 9: 789-792.

Hökfelt, T., and A. Ljungdahl (1970) Cellular localization of labeled gamma-aminobutyric acid $\left({ }^{3} \mathrm{H}-\mathrm{GABA}\right)$ in rat cerebellar cortex: An autoradiographic study. Brain Res. 22: 391396.

Hökfelt, T., and A. Ljungdahl (1972) Autoradiographic identification of cerebral and cerebellar cortical neurons accumulating labeled gamma-aminobutyric acid $\left({ }^{3} \mathrm{H}\right.$-GABA). Exp. Brain Res. 14: 354-362.

Hökfelt, T., and A. Ljungdahl (1975) Uptake mechanisms as a basis for the histochemical identification and tracing of transmitter-specific neuron populations. In The Use of Axonal Transport for Studies of Neuronal Connectivity, W. M.
Cowan and M. Cuenod, eds., pp. 249-305, Elsevier, Amsterdam.

Iversen, L. L. (1977) Inactivation of neurotransmitters. In Synapses, G. A. Cottrell and P. N. R. Usherwood, eds., pp. 137153, Academic Press, New York.

Iversen, I. I., and F. Schon (1973) The use of autoradiographic techniques for the identification and mapping of transmitter specific neurons in the CNS. In New Concepts in Neurotransmitter Regulation, A. Mandell, ed., pp. 153-193, Plenum Press, New York.

Johnson, J. L. (1978) The excitant amino acids, glutamic and aspartic acid, as transmitter candidates in the vertebrate CNS. Prog. Neurobiol. 10: 155-202.

Jones, D. R., and J. H. Casseday (1979) Projections of auditory nerve in the cat as seen by anterograde transport methods. Neuroscience 4: 1299-1313.

Jones, D. R., D. L. Oliver, S. J. Potashner, and D. K. Morest (1982) Retrograde axonal transport of $D$-aspartate from cochlear nucleus to type II spiral ganglion cells in the cat. Assoc. Res. Otolaryngol., Midwinter Meeting 5:90.

Kane, E. C. (1973) Octopus cells in the cochlear nucleus of the cat: Heterotypic synapses upon homeotypic neurons. Int. J. Neurosci. 5: 251-279.

Kane, E. C. (1974) Synaptic organization in the dorsal cochlear nucleus of the cat: A light and electron microscopic study. J. Comp. Neurol. 155: 301-330.

Kane, E. S. (1976) Descending inputs to caudal cochlear nucleus in cats: A horseradish peroxidase (HRP) study. Am. J. Anat. 146: 433-442.

Kelly, J. S., and F. Dick (1976) Differential labeling of glial cells and GABA-inhibitory interneurons and nerve terminals following the microinjection of $\left[\mathrm{B}-{ }^{3} \mathrm{H}\right]$ alanine, $\left[{ }^{3} \mathrm{H}\right]-\mathrm{DABA}$ and $\left[{ }^{3} \mathrm{H}\right]$ GABA into single folia of the cerebellum. Cold Spring Harbor Symp. Quant. Biol. 40: 93-106.

Kelly, J. S., F. Dick, and F. Schon (1975) The autoradiographic localization of the GABA-releasing nerve terminals in cerebellar glomeruli. Brain Res. 85: 255-259.

Kim, J. S., R. Hassler, P. Haug, and K. S. Paik (1977) Effect of frontal cortex ablation on striatal glutamic acid level in rat. Brain Res. 132: 370-374.

Kimura, H., P. L. McGeer, J. H. Peng, and E. G. McGeer (1981) The central cholinergic system studied by choline acetyltransferase immunohistochemistry in the cat. J. Comp. Neurol. 200: 151-201.

Kromer, L. F., and R. Y. Moore (1976) Cochlear nucleus innervation by central norepinephrine neurons in the rat. Brain Res. 118: 531-537.

LeVay, S., and H. Sherk (1981) The visual claustrum of the cat. I. Structure and connections. J. Neurosci. 1: 956-980.

Logan, W. J., and S. H. Snyder (1972) High affinity uptake systems for glycine, glutamic and aspartic acids in synaptosomes of rat central nervous tissues. Brain Res. 12: 113-431.

Lorente de Nó, R. (1933) Anatomy of the eighth nerve. III. General plan of structure of the primary cochlear nuclei. Laryngoscope 43: 327-350.

Lorente de Nó, R. (1981) The Primary Acoustic Nuclei, Raven Press, New York.

Malthe-Sorenssen, D., K. K. Skrede, and F. Fonnum (1979) $\mathrm{Ca}^{++}$-dependent release of $\mathrm{D}-\left({ }^{3} \mathrm{H}\right)$ aspartate evoked by selective electrical stimulation of excitatory afferent fibers to hippocampal pyramidal cells in vitro. Neuroscience 4: 1255-1263.

Malthe-Sorenssen, D., K. K. Skrede, and F. Fonnum (1980) Release of $\mathrm{D}-\left({ }^{3} \mathrm{H}\right)$ aspartate from the dorsolateral septum after electrical stimulation of the fimbria in vitro. Neuroscience 5 : 127-133.

Martin, M. R. (1980) The effects of iontophoretically applied antagonists on auditory nerve and amino acid evoked excitation of anteroventral cochlear nucleus neurons. Neuropharmacology 19: 519-528. 
Martin, M. R., and J. C. Adams (1979) Effect of DL- $\alpha$-aminoadipate on synaptically and chemically evoked excitation of anteroventral cochlear nucleus neurons of the cat. Neuroscience 4 : $1097-1105$.

McBride, W. J., M. H. Aprison, and K. Kusano (1976a) Contents of several amino acids in the cerebellum, brain stem and cerebrum of the "staggerer," "weaver" and "nervous" neurologically mutant mice. J. Neurochem. 26: 867-870.

McBride, W. J., N. S. Nadi, J. Altman, and M. H. Aprison (1976b) Effects of selective doses of x-irradiation on the levels of several amino acids in the cerebellum of the rat. Neurochem. Res. 1: 141-152.

McBride, W. J., M. A. Rea, and N. S. Nadi (1978) Effects of 3acetylpyridine on the levels of several amino acids in different CNS regions of the rat. Neurochem. Res. 3: 793-801.

McGeer, P. L., E. G. McGeer, U. Scherer, and K. Singh (1977) A glutamatergic corticostriatal path? Brain Res. 128: 369373.

Mesulam, M. M. (1978) Tetramethyl benzidine for horseradish peroxidase neurohistochemistry: A non-carcinogenic blue reaction-product with superior sensitivity for visualizing neural afferents and efferents. J. Histochem. Cytochem. 26: 106-117.

Morest, D. K. (1975) Synaptic relationships of Golgi type II cells in the medial geniculate body of the cat. J. Comp. Neurol. 162: 157-194.

Morest, D. K., N. Y. S. Kiang, E. C. Kane, J. J. Guinan, Jr., and D. A. Godfrey (1973) Stimulus coding at caudal levels of the cat's auditory nervous system: II. Patterns of synaptic organization. In Basic Mechanisms in Hearing, A. R. Møller, ed., pp. 479-509, Academic Press, New York.

Mugnaini, E., K. K. Osen, A. Dahl, V. L. Friedrich, Jr., and G. Korte (1980a) Fine structure of granule cells and related interneurons (termed Golgi cells) in the cochlear nuclear complex of cat, rat and mouse. J. Neurocytol. 9: 536-570.

Mugnaini, E., W. B. Warr, and K. K. Osen (1980b) Distribution and light microscopic features of granule cells in the cochlear nuclei of cat, rat, and mouse. J. Comp. Neurol. 191: 581-606.

Nadi, N. S., D. Kanter, W. J. McBride, and M. H. Aprison (1977) Effects of 3-acetylpyridine on several putative neurotransmitter amino acids in the cerebellum and medulla of the rat. J. Neurochem. 28: 661-662.

Nicoll, R. A., and B. E. Alger (1981) Synaptic excitation may activate a calcium dependent potassium conductance in hippocampal pyramidal cells. Science 212: 957-959.

Oliver, D. L., and W. C. Hall (1975) Subdivisions of the medial geniculate body in the tree shrew, Tupaia glis. Brain Res. 86: 217-227.

Oliver, D. L., D. R. Jones, S. J. Potashner, and D. K. Morest (1981) Evidence for selective uptake, release and axonal transport of $\mathrm{D}$-aspartate in the auditory system and cerebellum of cat and guinea pig. Anat. Rec. 199: 186A.

Pfeiffer, R. R. (1966) Anteroventral cochlear nucleus: Wave forms of extracellularly recorded spike potentials. Science 154: $667-668$.

Potashner, S. J. (1978) 'The spontaneous and electrically evoked release, from slices of guinea-pig cerebral cortex, of endogenous amino acids labeled via metabolism of $\mathrm{D}-\left(\mathrm{U}-{ }^{14} \mathrm{C}\right)$ glucose. J. Neurochem. 31: 177-186.

Roffler-Tarlov, S., and R. L. Sidman (1978) Concentrations of glutamic acid in cerebellar cortex and deep nuclei of normal mice and weaver, staggerer and nervous. Brain Res. 142: 269 283.

Rose, J. E., M. M. Gibson, L. M. Kitzes, and J. E. Hind (1973) Studies of phase-locked cochlear output in cells of the anteroventral nucleus in the cochlear complex of the cat. In Basic Mechanisms in Hearing, A. R. Møller, ed., pp. 511-518, Academic Press, New York.

Rubin, R. P. (1974) Calcium and the Secretory Process, Plenum Press, New York.

Ruggero, M. A., P. A. Sanli, and N. C. Rich (1982) Type II cochlear ganglion cells in the chinchilla. Hearing Res. 8: $339-356$.

Rustioni, A., and M. Cuenod (1982) Selective retrograde transport of D-aspartate in spinal interneurons and cortical neurons of rats. Brain Res. 236: 143-155.

Sandoval, M. E., and C. W. Cotman (1978) Evaluation of glutamate as a neurotransmitter of cerebellar parallel fibers. Neuroscience 3: 199-206.

Stevens, G. W. W. (1980) Protection against loss of silver grains from autoradiographs. J. Microsc. 120: 117-118.

Storm-Mathisen, J. (1981) Glutamate in hippocampal pathways. In Glutamate as a Neurotransmitter, G. DiChiara and G. L. Gessa, eds., pp. 43-56, Raven Press, New York.

Streit, P. (1980) Selective retrograde labelling indicating the transmitter of neuronal pathways. J. Comp. Neurol. 191: 429463.

Streit, P., and M. Cuenod (1979) Transmitter specificity and connectivity revealed by differential retrograde labeling of neural pathways. Neurosci. Lett. Suppl. 3: 340.

Streit, P., and J. C. Reubi (1977) A new and sensitive staining method for axonally transported horseradish peroxidase (HRP) in the pigeon visual system. Brain Res. 126: 530-537.

Takagaki, G. (1978) Sodium and potassium ions and accumulation of labeled D-aspartate and GABA in crude synaptosomal fraction from rat cerebral cortex. J. Neurochem. 30: 4756.

Tolbert, L. P., and D. K. Morest (1982a) The neuronal architecture of the anteroventral cochlear nucleus of the cat in the region of the cochlear nerve root: Golgi and Nissl methods. Neuroscience 7: 3013-3030.

Tolbert, L. P., and D. K. Morest (1982b) The neuronal architecture of the anteroventral cochlear nucleus of the cat in the region of the cochlear nerve root: Electron microscopy. Neuroscience $7:$ 3053-3067.

Tolbert, L. P., D. K. Morest, and D. Yurgelun-Todd (1982) The neuronal architecture of the anteroventral cochlear nucleus of the cat in the region of the cochlear nerve root: horseradish peroxidase labelling of identified cell types. Neuroscience 7: 3031-3052.

Wenthold, R. J. (1978) Glutamic acid and aspartic acid in subdivisions of the cochlear nucleus after auditory nerve lesion. Brain Res. 143: 544-548.

Wenthold, R. J. (1979) Release of endogenous glutamic acid, aspartic acid, and GABA from cochlear nucleus slices. Brain Res. 162: 338-343.

Wenthold, R. J. (1980) Glutaminase and aspartate aminotransferase decrease in the cochlear nucleus after lesion of the auditory nerve. Brain Res. 190: 293-297.

Wenthold, R. J., and R. L. Gulley (1977) Aspartic acid and glutamic acid levels in the cochlear nucleus after auditory nerve lesion. Brain Res. 138: 111-123.

Wenthold, R. J., and R. L. Gulley (1978) Glutamic acid and aspartic acid in the cochlear nucleus of the waltzing guinea pig. Brain Res. 158: 295-302.

Wenthold, R. J., and D. K. Morest (1976) Transmitter related enzymes in the guinea pig cochlear nucleus. Soc. Neurosci. Abst. 2: 28

Wiklund, L., G. Toggenburger, and M. Cuenod (1982) Aspartate: Possible neurotransmitter in cerebellar climbing fibers. Science 216: 78-80.

Young, A. B., M. L. Oster-Granite, R. M. Herndon, and S. H. Snyder (1974) Glutamic acid: Selective depletion by viral induced granule cell loss in hamster cerebellum. Brain Res. 73: 1-13.

Young, E. D. (1980) Identification of response properties of ascending axons from dorsal cochlear nucleus. Brain Res. 200: 23-37.

Young, E. D., and W. E. Brownell (1976) Responses to tones and noise of single cells in dorsal cochlear nucleus of unanesthetized cats. J. Neurophysiol. 39: 282-300. 